\title{
The Relationship between Efficiency and Quality of Municipally Owned Corporations: Evidence from Local Public Transport and Waste Management in Poland
}

\author{
Tomasz Jedynak ${ }^{1, *(\mathbb{D})}$ and Krzysztof Wąsowicz ${ }^{2}$ (D) \\ 1 Department of Risk Management and Insurance, Cracow University of Economics, 31-510 Kraków, Poland \\ 2 Department of Finance for Sustainable Development, Cracow University of Economics, 31-510 Kraków, \\ Poland; wasowick@uek.krakow.pl \\ * Correspondence: jedynakt@uek.krakow.pl
}

Citation: Jedynak, T.; Wassowicz, K. The Relationship between Efficiency and Quality of Municipally Owned Corporations: Evidence from Local Public Transport and Waste Management in Poland. Sustainability 2021, 13, 9804. https://doi.org/ $10.3390 /$ su13179804

Academic Editor: Edivando Vitor do Couto

Received: 30 July 2021

Accepted: 23 August 2021

Published: 31 August 2021

Publisher's Note: MDPI stays neutral with regard to jurisdictional claims in published maps and institutional affiliations.

Copyright: (c) 2021 by the authors. Licensee MDPI, Basel, Switzerland. This article is an open access article distributed under the terms and conditions of the Creative Commons Attribution (CC BY) license (https:/ / creativecommons.org/licenses/by/ $4.0 /)$.

\begin{abstract}
Sustainable development requires the intervention of public authorities in areas where market mechanisms do not guarantee the proper allocation of goods. Some of these goods include public services such as local collective transport and municipal waste management. In many countries, the process of remunicipalizing these service provisions is underway and, in the modern model used in providing these services, municipally owned corporations (MOCs) play a special role. The specific nature of these companies (i.e., the duality of their objectives and that they are required to run classic economic calculations while they are assessed in terms of the quality of their services) encouraged the authors to formulate the primary goal of the study, which was to assess the link between the financial and operational efficiency of MOCs and the quality of their services. The present study's authors developed a method for measuring the financial and operational efficiency of MOCs. In addition, a set of standards for assessing the quality of public service provision were defined, and opinion surveys were carried out to evaluate them. Subsequently, multi-criteria rankings of the efficiency and quality of services of the MOCs tested were drawn up using a synthetic variable based on the zero unitarization method (ZUM). A correlation of the analyzed variables was examined (Spearman's rank correlation coefficient) and simple line regression models were built. Our research showed that analyses of MOCs, when limited to their financial and operational aspects, are incomplete. According to the empirical analysis carried out, the financial and operational efficiency of MOCs does not translate to the quality of their services. Therefore, we believe that, in assessing the activities of MOCs, it is necessary to take into account criteria that measure the quality of meeting the needs of the local community in addition to financial criteria.
\end{abstract}

Keywords: public opinion; local government; public services; public utility services; municipally owned corporations; waste management; local public transport

\section{Introduction}

In today's urbanized world, sustainable socioeconomic development requires the involvement of public authorities in areas where market mechanisms do not guarantee the proper allocation of specific goods and services. Public services are a special type of service. These services should be identified by their specific objectives of an ongoing and uninterrupted meeting of the collective needs of the population through the provision of publicly available services, which are characterized by the state placing responsibility for their provision on public authorities [1,2]. Among public utility services, a special position is held by services provided at the local level, i.e., those for which local authorities are responsible. They may carry out the tasks imposed on them directly, through local bureaucracy, or by outsourcing them to other entities $[3,4]$.

With the development and popularization of market concepts in the early 1980s, a strong trend emerged towards privatizing the provision of public services, resulting in 
many tasks being outsourced to private entities [5]. Since the beginning of the 21st century, however, the privatization trend has reversed and many countries have experienced a process of remunicipalization of local public service provision [6-8]. In today's model of providing these services, municipally owned corporations (MOCs) play a particular role. They are defined as "autonomous organizations owned by municipalities, used to produce or deliver local public services outside the local bureaucracy" [9]. The increasing importance and specific nature of these entities have led to increasing discussions in recent literature about how they function and operate [9-16].

In addition to their organizational and legal form, ownership structure, and the nature of the services provided, the specificity of MOCs is manifested in the duality of the objectives set before them. On the one hand, as economic entities operating in the form of commercial legal companies, they are required to include classic economic calculations (i.e., the pursuit of efficiency) in their activities. On the other hand, the specificity of the services they provide means that they are assessed in terms of the quality of those services. The quality requirements for local public services are placed by their consumers (i.e., residents) and enforced by local authorities chosen by those residents. Therefore, the correct assessment of the functioning of these MOCs should include both the efficiency criteria typical of market players and the qualitative criteria required of public services.

The relationship between economic efficiency and quality of services in typical enterprises has been widely discussed in the literature [17-21]. Findings formulated in these publications have indicated that, in order to pursue financial stability and profits, entities need to improve their performances, particularly in terms of quality. In the case of MOCs, however, this issue has thus far been underrepresented in the literature. To date, performance analyses of MOCs have been undertaken in only a few studies. Furthermore, these studies focused mainly on only one of the discussed aspects [9,14,22-26].

In view of the above, the following question was formulated as a basis for the research issues undertaken in the study:

- Does the financial and operational efficiency of municipal enterprises translate into the quality of the services they provide in the eyes of citizens?

In relation to this specific research problem, the main research hypothesis to be verified in this research project was formulated as follows:

Hypothesis H1. The financial and operational efficiency of municipal enterprises is associated with the quality of their services.

Following the research hypothesis, the objectives of the study were formulated. Theoretical objectives included defining the characteristics of MOCs, determining how their financial and operational efficiency was measured, and the quality characteristics of services provided by those entities. The methodological objective was to develop a methodology for determining the financial and operational efficiency of MOCs and testing and evaluate the quality of their provision of public services. The primary research objective, on the other hand, was to assess the link between the financial and operational efficiency of municipal undertakings and the quality of their services.

Among the different types of local public services analyzed in the subject literature, the study examined, in detail, local public transport services and municipal waste management. First, we developed a method for measuring the financial and operational effectiveness of MOCs. Our method used measures common in financial analysis but proposed original indicators. The values of each measure were calculated on the basis of data published in public databases and information obtained from the analyzed MOCs. A set of 10 standards was then defined for assessing the quality of public services. An opinion survey was carried out on these standards among the inhabitants of the eleven largest cities in Poland. In the analytical phase of the study, in order to compare the financial and operational efficiency and quality of the services provided by the audited enterprises, multi-criteria rankings of the effectiveness and quality of the services provided by the audited enterprises were 
created using a synthetic variable, the design of which was based on zero unitarization. Additionally, the correlation of the analyzed variables (Spearman rank correlation coefficient) was examined, and simple linear regression models were constructed.

The contribution of this study to theoretical discussions on the functioning of MOCs is to present the dissonance between their objectives as market players and the public interest prevailing in the delivery of public utility services. The study also sheds new light on how MOCs define and test financial and operational efficiency. The authors also present a new approach to the quality of public services, highlighting their reliability, social satisfaction, and impact on sustainable development. Empirically, the study presents the results of applying an original research model for MOCs performance synergies by using taxonomic methods to rank entities by selected characteristics and measures. Unlike most local public services studies, this study does not focus solely on a single industry but covers local public transport and municipal waste management.

\section{Literature Review-Providing Local Public Services and Municipally Owned Corporations}

\subsection{Local Collective Transport and Municipal Waste Management as Local Public Services}

The provision of public services is one of the main tasks of public administration. In general, public services are services designed to serve all members of a given community. Public services generally have the characteristics of typical public goods, common goods, club goods, or merit goods. Terminology discussions on how to define these types of goods in the context of public goods have already been the subject of theories in the early publications discussing public sector economics [27-31]. This issue is also present in many of the fundamental contemporary studies [1,32-34]. Thus, without adopting strict definitions of the concept of public goods and services, it is accepted that the majority of public services are services which, according to accepted social standards, are insufficiently provided by the market.

In the traditional core literature on the topic, public services include services that are provided by different public administrations within the welfare state. However, as a result of the development of the new public management concept, in many countries today, the state is no longer regarded as the only provider of public services [35-37]. It is accepted that authorities may provide such services both directly (within the public sector) and through private sector entities, non-government organizations (NGOs), or third-sector institutions, as well as in the form of public-private partnerships. As a result, the term "public services" is becoming increasingly ambiguous.

In this context, the contemporary understanding of the idea of public services seems to be accurately reflected by the European Commission's approach [38], in which those services are referred to as services of general interest (SGIs). According to the Commission, SGIs are services, "which the public authorities of the EU Member States classify as services serving the general good and which are therefore subject to specific public service obligations" [38]. According to the Commission, these services support the European social system and social market economy model. SGIs are an essential aspect of promoting economic, social, and territorial cohesion and the development of a sustainable European Union. The main objective of providing these services is to protect citizens from harmful social consequences by seeking to guarantee universal access to basic goods and services and fundamental rights.

In this context, the European Commission distinguishes three categories of SGIs: (1) services of general economic interest (essential services provided on a fee basis); (2) noneconomic services (provided for free); (3) social services of general interest, which meet the needs of citizens from the most vulnerable groups and are based on the principle of solidarity and equal access. The considerations presented in this study focus mainly on the first of these categories, i.e., areas such as water and energy supply, waste water disposal, waste management, public transport, health, social services, telecommunication services, culture, radio, and television. 
In the literature, SGIs are also referred to as key services, basic public services, or essential services [39]. In addition, some authors use the term "public services" when referring to the concept behind SGIs, which are defined as services to which all citizens have "equal rights to access and to enjoy" [40]. In order to avoid ambiguity and problems of interpretation, the concept of "public services" will also be used later in this article in the sense defined above.

The organization of the public service system is the responsibility of the public administration. Depending on the nature of the service, this responsibility may lie with central administration (e.g., social security systems), government agencies (e.g., emergency services), or local government units (e.g., waste management). In this study, we addressed public services provided at the local level, which we further defined as "local public services". Among the different types of such services, we examined, in detail, local public transport and municipal waste management services.

Much of local public transport is due to the nature of modern human and economic activities, which are associated with the need to move between locations. People move to meet their basic needs related to traveling to work, school, shop, office, hospital, etc. Local collective transport can be used in urban areas for this purpose. Public transport allows citizens of a given city to move effectively from one place to another. It has a direct impact on the quality of life, in particular for the most vulnerable who do not have the means to buy their own means of transport or cannot use it on grounds of disability. In addition, local collective transport, which gains customers from among those who own and can use cars, contributes to reducing noise and emissions, minimizing road congestion and accidents, generating additional positive externalities, and improving the overall quality of life in the city [41].

Municipal waste management is the foundation for the proper functioning of the community living in an area. The generation of individual waste by residents requires its collective handling (management). This service consists of the collection, transport, and treatment of such waste, as well as the supervision of these activities. Waste management is an indispensable area of activity that ensures the protection of human life and health and of the environment. In principle, without the existence of waste management, the development of modern civilization cannot be discussed in any aspect [42-44].

\subsection{Municipally Owned Corporations as a Form of Provision of Local Public Services}

In recent decades, with increasing decentralization, the importance of public services provided at the local level has increased significantly. Forms of local public service provision can be classified based on the degree of demonopolization and privatization. On the basis of these two criteria, taking into account the organizational and ownership aspects, different possible models of organizing the provision of public services are distinguished (Figure 1), which, in current European practice, are limited to those where the leading role is played by public entities at all levels.

From an organizational and legal point of view, the system for providing these services can take different forms. Local authorities providing public services may [15] have the following features:

- Provide certain services on their own (through the civil service);

- $\quad$ Privatize or outsource to private entities the provision of selected services;

- Provide services jointly with other entities, informally in the form of inter-municipal cooperation or public-private partnerships;

- $\quad$ Provide services through municipally owned corporations. 
Organi zational centralization criterion for regulatory sphere

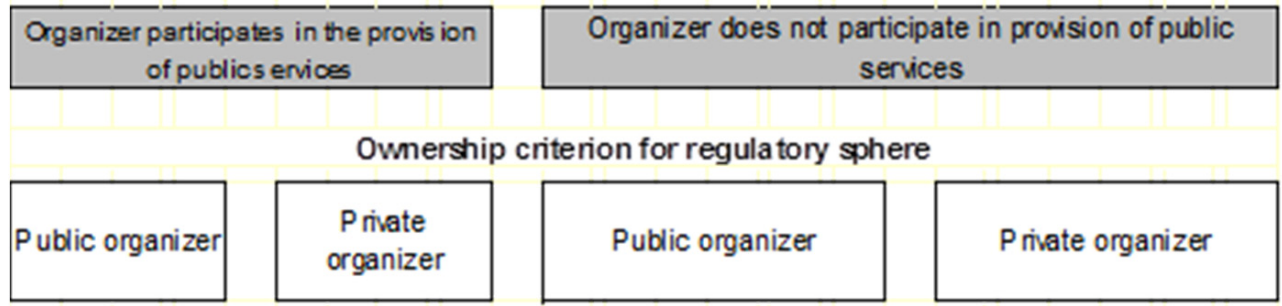

Organi zational centralization criterion for sphere of implementation
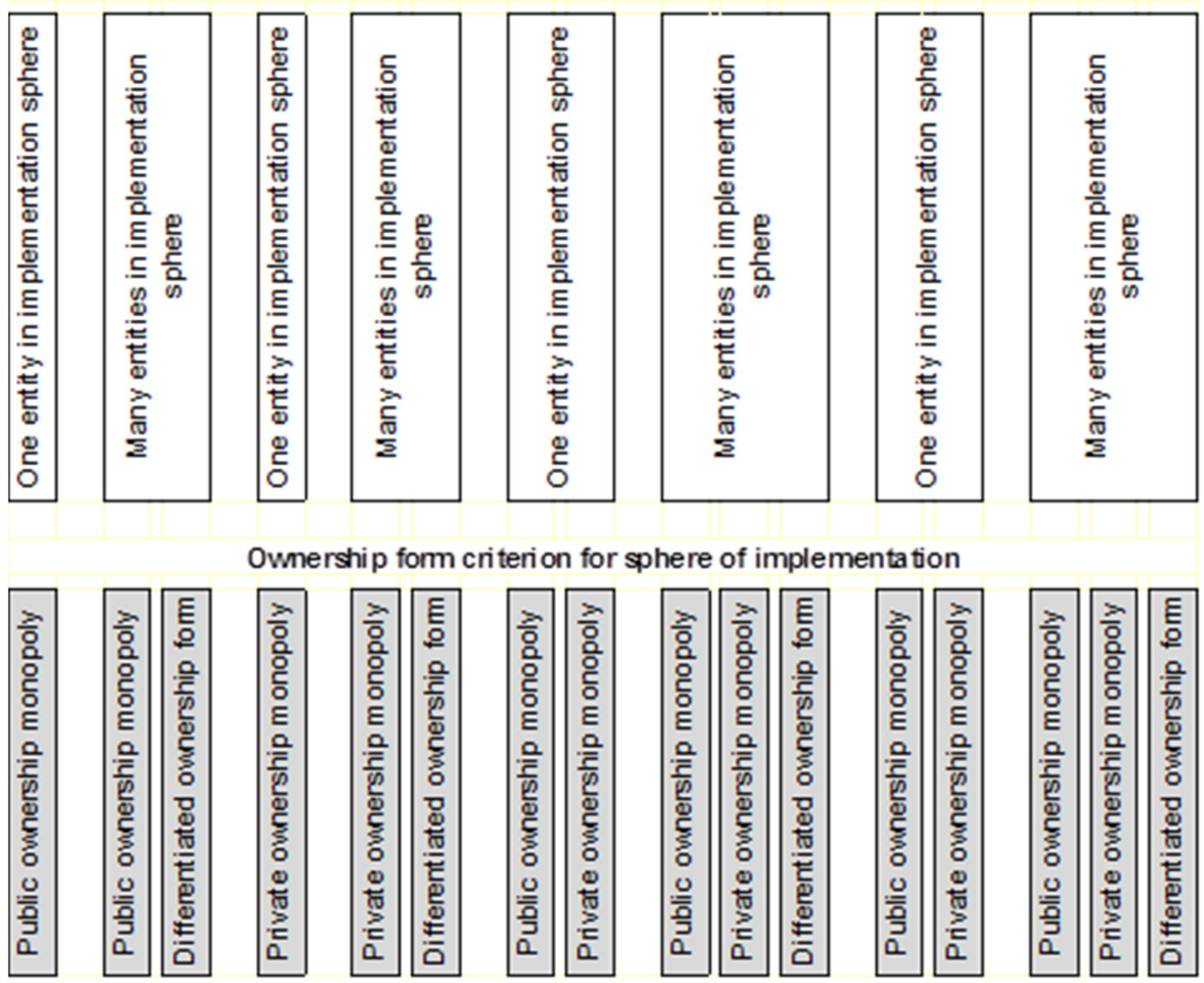

Figure 1. Examples of models of the organization of local public services.

Issues related to various forms of public service provision, including local public services, are widely analyzed in the subject literature. One of the more popular topics concerns the form of public service provision [45]. The most common ways of providing such services are the independent provision of services by government bodies; contracts with other governments, private companies, or non-profit organizations; joint servicedelivery arrangements. A mixed approach is also possible, in which local authorities decide to share public service obligations with private providers. Provision of services in this formula allows for the assessment of contractual form effectiveness while maintaining the local government unit's own potential [46-48]. Research suggests that certain choices regarding the form of provision of public services show strong inertia [45].

The literature also raises the question of reforming the way in which public services are provided and highlights the dominant role of privatization in these reforms [49]. The question of institutional reform of public service provision goes beyond privatization and also includes other forms of provision of those services, such as municipal corporations, relational contracting, and dynamic market management. Other approaches discussed in the literature include comparing the economies of scale and efficiency of privatization and inter-municipality cooperation [50] and comparing contracts with for-profit and non-profit organizations [46]. The last studies show that in terms of cost, quality of work, response 
to decision-maker requirements, legality, and level of customer satisfaction, there are no significant differences in the performance of services provided by non-profit organizations and profit-oriented enterprises. Research is also being carried out on transaction costs as a criterion for choosing between different forms of provision of local public services [51-53].

From the perspective of the quality of service provided to members of the local community, the effects of its different forms have been analyzed by Cuadrado-Ballesteros, García-Sánchez, and Prado-Lorenzo [22]. Using empirical data, they found that quality of life is higher in municipalities where local government benefits from functional decentralization. At the same time, when the analysis took into account the private sector, the results were ambiguous, i.e., quality of life was higher in municipalities where public transport and healthcare services were provided by public undertakings and in those municipalities where urban services were provided by foundations (charities) or autonomous organizations. Moreover, resident quality of life was higher when water management services were provided by external entities or by mixed companies.

In more recent studies, Pérez-López, Prior, and Zafra-Gómezhave analyzed the opportunities for municipalities to choose different methods of providing public services [25]. Looking at the effectiveness of the various forms of public service provision in Spain, they concluded that modern forms of service provision, such as agency creation, external contracting, and inter-municipality cooperation, reduce cost-effectiveness. At the same time, it was observed that during the global recession some of these forms were more effective than traditional ways of providing public services. Research carried out among Dutch local authorities, which analyzed factors affecting the choice of certain forms of public service provision, shows that a positive impact on the choice of service privatization, e.g., the right-wing political orientation of the municipal council, focuses on the model of municipality management (emphasis on performance indicators) and the weaker financial situation of the municipality [54].

In addition to the works discussed above, which are of a general nature and focus on comparing the different ways of providing local services, a large number of studies conduct detailed analyses of the advantages and disadvantages, efficiency, effectiveness, and costs associated with the chosen methods of providing these services. In earlier studies, other authors analyzed the issue of contracting the provision of local public services [46,53,55-57]. Other articles addressed the issue of privatization of local public services [58,59]. Public-private partnerships in the provision of public services have been studied using the examples of transport infrastructure in The Netherlands [60], Italian solutions [61], and US wireless broadband [62]. Among research threads, there are also issues regarding the importance of nonprofit organizations in providing local public services [63] and inter-municipal cooperation [64-67].

Decision making on how to provide local public services has also been studied in a number of other studies [23,68-70]. A comprehensive overview of studies on the different methods of providing public services, as well as other studies not mentioned here, includes publications based on meta-analyses [71,72]. Voorn [15] also carried out a notable literature review. Moreover, it is also worth noting the study by Bel and Gradus [73], in which the authors extensively discussed the results of the latest studies on contracting out, privatization, and inter-municipal cooperation and identified factors influencing the choice of a specific form of public service provision.

The undertaken literature review allows for the conclusion that the issue of forms of provision of public services at the local level is relatively well recognized in many different aspects (criteria for the choice of a particular form by local authorities, the efficiency and effectiveness of different forms, externalities and transaction costs associated with individual forms, the quality of services for citizens, etc.). Extensive knowledge regarding the provision of public services by local authorities on their own or through privatization, outsourcing to private entities and inter-municipal cooperation, and public-private partnerships is in stark contrast with knowledge regarding the provision of these services by municipal enterprises [15]. Of the same opinion are other authors who have recently 
called for in-depth research into the phenomenon of corporatization and MOCs in local authorities $[9,12,74,75]$.

An underlying reason for the relatively low prevalence of MOCs in the literature is a widespread belief among many researchers that the provision of public services through them is not fundamentally different from the standard model for the provision of such services through the local civil service. This belief stems from a widespread tendency to focus on the analysis of different forms of public service provision on the dichotomy of the forms of service provider ownership (private property vs. public property). However, recent studies show that other factors are also relevant in such analyses, including competition-related issues, which significantly differentiate MOCs from traditional forms of public service provision [15].

The concept of municipally owned corporations is ambiguous, and several synonyms are used in parallel in the literature. Other authors, to name entities that we refer to as MOCs, use the terms "municipal enterprises" [11,76,77]; "municipal corporations" [10,78]; "municipal companies" [79,80]; "municipally owned companies" [81]; "municipally owned enterprises" [12,82]; "local government companies" [13]. In the past, the term "municipally owned firms" [83,84] was also used, which some authors also use today [85]. In the USA, entities of a MOC-like nature are the "public authority" [26]. A concept similar in nature to MOCs is that of the "public utility company", which defines all entities providing a particular type of public service [5].

The term "municipally owned corporation" was first used in the work of Tavares and Camões [86] and currently is widely used and well established in the literature $[4,9,14,16,87]$. Similar to Voorn [15], we believe that this term best reflects the essence of the entities that are analyzed in this study. On the one hand, it emphasizes that their owners or co-owners are local authorities and independent corporate status. On the other hand, it does not suggest the full market nature of those entities, as in the case of the terms "enterprise", "company", or "firm". The term also directly refers to the phenomenon known as the corporatization of public services, which is at the root of the growing popularity of MOCs [12,13,74].

The characteristics of MOCs that distinguish them from other forms of provision of local public services include $[9,14,61,78,86]$ the following:

- Operating under private law and having independent corporate status (including the right to own property and right to sue or be sued);

- MOCs in carrying out public tasks have no right to impose taxes, and their financial management is based on revenues in the form of fees or transfers financed by local authorities;

- As a rule (but not in every country), MOCs can generate profits, but they can also suffer losses and face the risk of bankruptcy;

- In general, MOCs provide one type of service (usually transport, waste management, or water supply and wastewater disposal), although in some countries (including Poland), MOCs can provide many different public services at the same time.

An important feature of MOCs is also their control by one or more local government units in the form of ownership of majority stakes in the commercial law companies, whose form MOCs take. This does not mean that only local government units can be shareholders of those entities. On the contrary, part of the shares may also be held by private sector entities.

In view of the above, MOCs in this study are defined as entities with the following features:

- Providing a specific type of service to local communities;

- Operating on the basis of private law and having a separate legal personality;

- The majority of their shareholders are local authorities;

- Managed by a management board appointed by local authorities, which exercise ownership of those entities;

- Generating revenues from fees charged to the recipients of their services or framework contracts concluded with a local authority for the performance of specific tasks. 
On the basis of these considerations, in Table 1, MOCs have been placed in the system for the provision of local public services in the fields of public transport and municipal waste management.

\subsection{Efficiency of Municipally Owned Corporations}

In a market economy, all entities must make effective use of their financial resources, personnel resources, maintain existing and acquire new customers, streamline their processes and technology and implement efficient management methods. This requires determining whether the undertaken activity is delivering the intended results. This approach is combined with the concept of efficiency, which should be understood as the best results for the production or distribution of goods and services at specified costs or as low as possible for the effects in question [88]. Classically computed economic efficiency is therefore the result of the actions described by the relationship of effects to expenditure. Various types of synthetic indicators are used to measure this efficiency, indicating the efficiency of the company (e.g., return on assets (ROA); return on equity (ROE)). However, it should be noted that efficiency can also be considered in relation to other aspects of the management process. In addition to financial efficiency, efficiency is also defined as organizational (technical production), operational, environmental, qualitative, social, ethical-cultural, etc.

In the literature, the issue of defining the concept of MOC efficiency and how it is measured has not been a priority thus far. In most studies, the understanding of these terms coincides with the way they are perceived in relation to typical market enterprises. Studies that have adopted such a way of understanding efficiency focus mainly on comparing the efficiency of different forms of public service provision, with particular regard to the distinction between public and private forms of ownership of service providers [14]. The key success factors of MOCs from the perspective of surveying the opinions of professionals were studied by Daiser and Wirtz [81]. Cuadrado-Ballesteros, García-Sánchez, and PradoLorenzo [22] analyzed the impact of MOCs on resident quality of life. In a multi-criteria sense, the effectiveness of MOCs was analyzed by Voorm, van Genugten, and van Thiel [14]. In their opinion, MOC performance consists of effectiveness, efficiency, and quality, which are subjectively perceived by the managers of these entities.

An extensive meta-analysis of the results of the studies carried out in the field of MOC efficiency was presented by Voorn, van Genugten, and van Thiel [9]. The main conclusion of this research is that MOCs are more efficient than local bureaucracies in providing typical public services (waste management, local transport, water management). Among studies supporting this thesis are [22,23]. Albalate, Bel, and Calzada [24] found that Spanish MOCs are only effective if they operate in a competitive market and feel pressure from other operators. On the other hand, according to Pérez-López, Prior, and Zafra-Gómez [25], depending on the industry, MOCs are more (e.g., waste management, water management) or less (e.g., public transport) effective than traditional forms of public service provision. Da Cruz and Marques [79], in their analysis of MOCs in Portugal, arrived at the opposite conclusion, that MOCs are less efficient than local bureaucracies. The second important conclusion of MOC efficiency research is that, when compared to other forms of public service provision, they have a high initial failure rate [26,79]. 
Table 1. Basic models for the organization of the provision of public services in Europe.

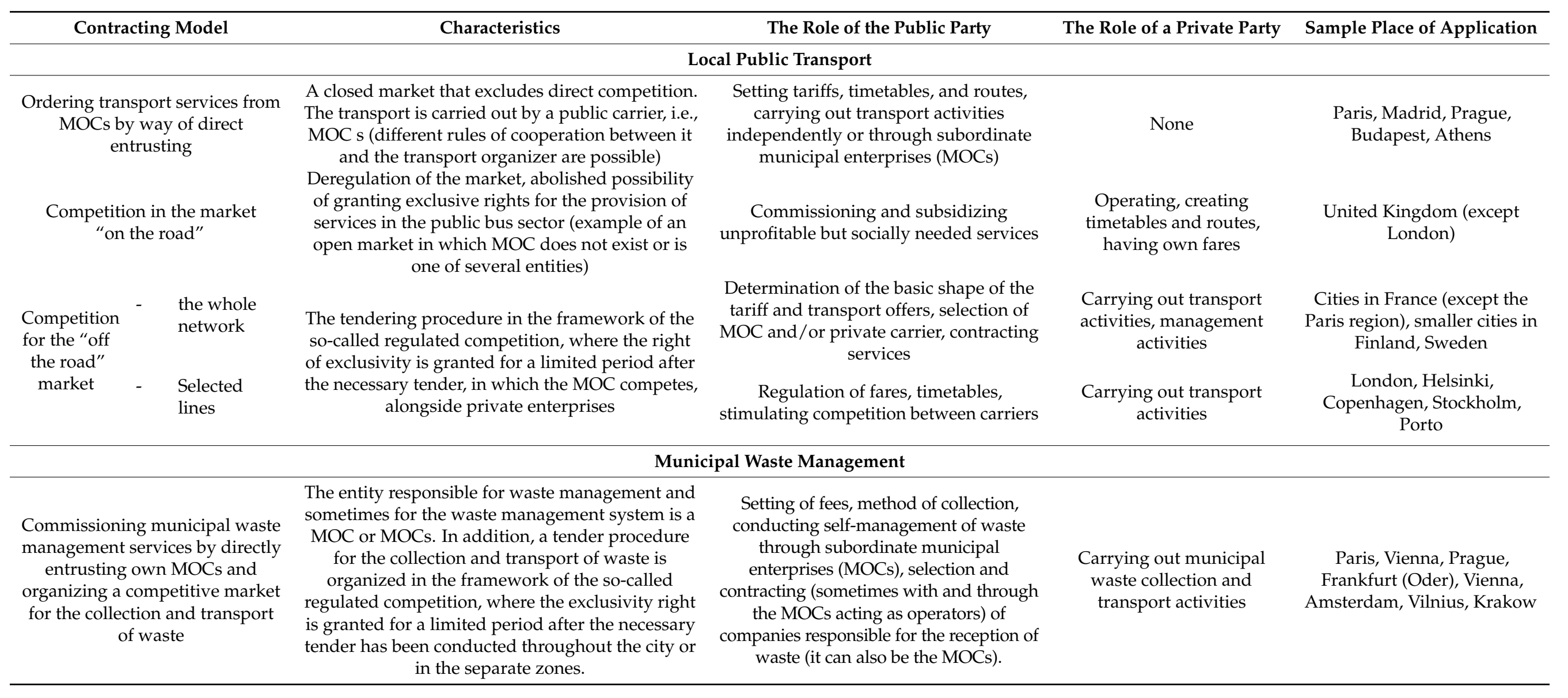


Table 1. Cont

\section{Contracting Model}

\section{Characteristic}

A tender procedure is organized for the

management of collection, transport of waste

Competition for the municipa

waste management and

collection market

Partial competition in the municipal waste management

market within the framework of the so-called regulated

competition, where the right of exclusivity is granted for a limited period after the necessary tender has been carried out. Sometimes a MOC or a private entity is selected, operating on publicly owned equipment.

Municipalities organize waste management on he basis of a competitive market model, but large waste producers, such as housing associations, can exit the municipal system and contract directly with private operators or MOCs

\section{The Role of the Public Party}

Setting of fees, method of collection, management, selection, and contracting of companies (including MOCs)

responsible for the implementation of municipal waste management

Setting of fees, method of collection, management, selection, and contracting of enterprises (including MOCs)

responsible for the implementation of

municipal waste management in a system without larger entities

\section{The Role of a Private Party}

Sample Place of Application

Carrying out municipa waste management, collection, and transport activities

London, Valencia, Marseille Eindhoven, Frankfurt am

Main

Conducting municipal waste management activities in the organizational, financial, and operational areas
Sofia, Turku, Lahti, Cork 


\section{Materials and Methods}

Compared to other businesses, municipally owned corporations (MOCs) have additional responsibilities towards local communities, which arise from the ownership structure of those entities and from the specific nature of the local public services they provide. MOCs are required to be viable and effective in achieving the objectives set before them, which take into consideration issues such as the quality of the services provided. In particular, the functioning of local public transport enterprises and municipal waste management undertakings should focus on both maximizing financial and operational efficiency, and improving the quality of life of society. Therefore, when analyzing the effectiveness of their activities, it is necessary to move beyond the framework of typical economic analyses.

In our view, proper assessment of the functioning of MOCs required simultaneous consideration of financial and operational criteria together with quality criteria, which relate to the degree of satisfaction in fulfilling the needs of the local community. Importantly, the quality of services provided by MOCs should be assessed directly from the perspective of the recipients of their services (residents) and not from the perspective of artificial measures created from the perspective of desk-bound analysis.

In view of the above, the analysis of the effectiveness of MOCs was carried out on a multidimensional basis, simultaneously analyzing their financial and operational efficiency and the quality of the services they provide assessed by their customers (Table 2). This approach, therefore, covers both the business-provider perspective (operational and financial efficiency) and the consumer-residents' perspective (quality). The accepted test methodology is expressed in two specific hypotheses that correspond to the main research hypothesis (H1) set out in the introduction and were formulated for MOCs operating in the analyzed industries as follows:

Hypothesis H2. Measured by indicators of operational and financial efficiency, the efficiency of municipal enterprises providing local public transport services is associated with the quality of these services perceived by residents.

Hypothesis H3. Measured by indicators of operational and financial efficiency, the efficiency of municipal enterprises providing municipal waste management services is associated with the quality of these services perceived by residents.

These hypotheses were verified in the course of the empirical studies and discussed in the following sections.

Table 2. Efficiency of MOCs from the perspective of the supplier and the consumer.

\begin{tabular}{|c|c|c|c|c|c|c|}
\hline Perspective & \multicolumn{4}{|c|}{ Supplier (Efficiency) } & \multirow{2}{*}{\multicolumn{2}{|c|}{$\begin{array}{c}\text { Consumer (Quality) } \\
\text { Quality Meters }\end{array}$}} \\
\hline $\begin{array}{l}\text { Performance } \\
\text { Dimension }\end{array}$ & \multicolumn{2}{|c|}{ Operational Efficiency Measures } & \multicolumn{2}{|c|}{ Financial Performance Measures } & & \\
\hline MOC industry & $\begin{array}{l}\text { Local public } \\
\text { transport }\end{array}$ & $\begin{array}{c}\text { Municipal waste } \\
\text { management }\end{array}$ & $\begin{array}{l}\text { Local public } \\
\text { transport }\end{array}$ & $\begin{array}{l}\text { Municipal waste } \\
\text { management }\end{array}$ & $\begin{array}{l}\text { Local public } \\
\text { transport }\end{array}$ & $\begin{array}{l}\text { Municipal waste } \\
\text { management }\end{array}$ \\
\hline Measurements & $\begin{array}{l}\text { rate and } \\
\text { intensity of } \\
\text { rolling } \\
\text { stock } \\
\text { (vehicle use } \\
\text { index, VUI) }\end{array}$ & $\begin{array}{ll}- & \text { level of } \\
& \text { recycling } \\
(L R)\end{array}$ & $\begin{array}{ll}\text { - } & \text { profitabili } \\
\text { ROE, ROA } & \text { financial p } \\
\text { indicators } \\
\text { - } & \text { financial a } \\
\text { servicing } ~ \\
\text { - } & \text { cost per } \\
\text { vehicle } \\
\text { kilometer } \\
\text { (truck cost } \\
\text { index, } \\
\text { CVK) }\end{array}$ & $\begin{array}{l}\text { dicators (ROS, } \\
\text { rmance } \\
\text { and debt } \\
\text { (CR, DR) } \\
\text { - Recycling } \\
\text { cost index } \\
\text { (RC) } \\
\text { indicator }\end{array}$ & $\begin{array}{l}\text { aggregated } \\
\text { quality } \\
\text { index of } \\
\text { local } \\
\text { transport } \\
\text { services } \\
\text { (AMULT) }\end{array}$ & $\begin{array}{ll}\text { - } & \text { aggregated } \\
\text { quality of } \\
\text { waste man- } \\
\text { agement } \\
\text { service } \\
\text { index } \\
\text { (AMUWM) }\end{array}$ \\
\hline
\end{tabular}




\subsection{Operational Efficiency}

The operational efficiency assessment of the local public transport undertakings examined was carried out on the basis of the vehicles usage index (VUI). This indicator determines how many vehicle kilometers are completed by the rolling stock (transport vehicles) used by public transport companies in one vehicle hour. By juxtaposing within a single measure of the operating work expressed in vehicle kilometers and the operating work expressed in vehicle hours, the VUI indicator allows for a synthetic measurement of the efficiency of the public transport company.

$$
V U I_{i}=\frac{T V C_{i}}{T V H_{i}}
$$

where $T V C_{i}$ - the numbers of vehicle kilometers driven by the organization's rolling stock (transport vehicles) during the period $i ; \mathrm{TVH}_{i}$-the number of vehicle hours traveled by the rolling stock during the period $i$.

The number of vehicle kilometers in the counter of the formula for the value of the rolling stock intensity index is a measure indicating the amount of work carried out in a local public transport enterprise. The total number of vehicle kilometers driven over a given period $\left(T V C_{i}\right)$ determines the operational work of the transportation rolling stock-it measures the total distance traveled by all public transport vehicles. Hence,

$$
T V C_{i}=\sum_{q=1}^{n} V C_{i}^{q}
$$

where $V C_{i}^{q}$-presented in vehicle kilometers operation of the $q$-th transportation (transit) route during the period $i$; - the total number of transportation routes in the city.

The operational work for each transportation route shall be determined as the sum of the length of the trips completed by all vehicles in all trips as follows:

$$
V C_{i}^{q}=\sum_{j=1}^{m_{i}^{q}} c l_{i j}^{q}
$$

where $c l_{i j}^{q}$-the length of the $j$-th trip of the $q$-th transportation route during the period $i$; $m_{i}^{q}$ - the number of trips of the $q$-th transportation route in the period $i$.

The number of hours is a measure of operational work in transportation (transit) enterprises. Total number of hours traveled during a given period $\left(T V H_{i}\right)$ shows the sum of the journey times of public transport vehicles on all trips of the transport route.

$$
T V H_{i}=\sum_{q=1}^{n} V H_{i}^{q}
$$

where $\mathrm{VH}_{i}^{q}$-the operating work of the $q$-th transportation route in the period $i$; $n$ - the total number of transport routes in the city expressed in vehicle hours.

The working hours expressed in vehicle hours for each transportation route shall be expressed as follows:

$$
V H_{i}^{q}=\sum_{j=1}^{m_{i}^{q}} t_{i j}^{q}
$$

where $t_{i j}^{q}$-the duration of the $j$-th trip of the $q$-th transport route during the period $i$; $m_{i}^{q}$ - the number of courses of the $q$-th transportation route during the period $i$.

When assessing the operational efficiency of municipal waste management companies, the concept of recycling levels is used. This concept is outlined in Directive 2008/98/EC of the European Parliament and is implemented into the Polish legal system by the Law 
on the Maintenance of Cleanliness and Order in Municipalities (Journal of Laws 2017, item 1289). Under current regulations, municipalities are required to calculate their own recycling rates for different waste fractions. Detailed guidelines in this area are provided by national law.

This article uses the recycling and preparation rate for reuse of paper, metal, plastics, and glass $(L R)$ calculated in these companies to determine the operational efficiency of municipal waste management companies. The value of this indicator is determined according to the following formula:

$$
L R=\frac{M W_{R}}{M W_{T}} \cdot 100 \%
$$

where $L R$-level of recycling and preparation for reuse of municipal waste; $M W_{R}$-the total weight of waste of a particular type recycled and prepared for reuse by the enterprise concerned; $M W_{T}$ - the total weight of the waste of a certain type collected by the enterprise concerned.

The study assumes that the recycling rate achieved in such a manner is the primary indicator of the operational efficiency of waste management in a given city. This is because high recycling levels are a challenge for municipal enterprises, which are in fact involved in waste management in the city. Therefore, a universal measure of the effectiveness and efficiency of these entities can be the level of recycling for the raw material fraction in a given city.

\subsection{Financial Efficiency}

Standard financial analysis indicators [89] were used in the assessment of MOC financial effectiveness. In particular, calculations centered on the values of the following measures:

- $\quad$ Profitability (return on net sales (ROS); return on equity (ROE); return on total assets (ROA));

- $\quad$ Total assets turnover (TAT);

- Current ratio (CR);

- Debt ratio (DR).

In addition, due to the specificity of the activities of local public transport companies, their financial efficiency was also assessed on the basis of the cost per vehicle-kilometer $(C V K)$ index. This indicator synthetically shows the average cost of driving one kilometer by a public transport vehicle. The $C V K$ indicator in economic practice is widely used by public transport operators. After a modification by the research authors, it takes the form of

$$
C V K_{i}=\frac{T C_{i}}{T V C_{i}}
$$

where $T C_{i}$ - the total operating costs of the enterprise during the period $i$; $T V C_{i}$ - the number of vehicle kilometers traveled by the rolling stock of the enterprise during the period $i$.

Taking into account the specificities of municipal waste management companies and in the study of their financial efficiency, the cost of recycling $(R C)$ indicator was used in addition to classical financial indicators. The design of this indicator is based on the assumption that a given level of recycling should be achieved with as few resources as possible. Hence, this indicator takes the form of

$$
R C_{i}=\frac{T C_{i} / T W_{i}}{R R_{i}}
$$

where $T C_{i}$ - the total operating costs of the enterprise during the period $i ; T W_{i}$-the mass of the waste collected during the period $i ; R R_{i}$-the degree of recycling of municipal fractions achieved during the period $i$. 
The $R C$ ratio value, therefore, indicates what amount of money was required to achieve a specific level of recycling.

\subsection{Quality of Local Public Services}

The treatment of the concept of quality of municipal services as a set of characteristics describing that quality from the point of view of their recipient (resident) was the starting point for determining the set of characteristics for the quality level of services analyzed in this article-local public transport and municipal waste management. In view of the general expectations taken into account in assessing the quality of public services [90] and the conditions for collective transport and municipal waste management in urban areas [91-94], a set of standards was developed to define the quality of the municipal economy in the city (Table 3). These standards reflect the preferences reported by residents towards the municipal economy sectors surveyed. These characteristics are further referred to as quality standards for municipal services.

Table 3. Standards determining the quality of municipal services.

\begin{tabular}{|c|c|c|}
\hline $\begin{array}{l}\text { Qualitative Dimension of the } \\
\text { Provision of Municipal Service }\end{array}$ & Local Public Transport & Municipal Waste Management \\
\hline Accessibility/comprehensiveness & Availability of the transportation network & Comprehensive collection \\
\hline Frequency & Frequency of running & Frequency of collection \\
\hline Punctuality/timeliness & Punctuality of running & Timely collection \\
\hline Safety & Travel safety & Winter infrastructure maintenance \\
\hline Certainty & The certainty of completing a planned trip & Certainty of waste collection \\
\hline Speed/effectiveness & Immediacy and speed of travel & Maintaining cleanliness in the city \\
\hline Cost & The level of transport fees & The level of the collection fee \\
\hline Convenience & The convenience of travel & Ease of waste segregation \\
\hline Information & Information about the transport offer & Information about the waste collection offer \\
\hline Modern technologies & Use of modern technologies & Use of modern technologies \\
\hline
\end{tabular}

In order to measure the quality of the provision of municipal services from the consumer point of view, a proprietary research questionnaire was developed, which included a set of questions on the distinguished standards for the provision of those services. The full questionnaire consisted of 41 detailed questions regarding the quality of municipal services in two analyzed sectors (there were more than one question regarding some standards). To increase the relevance of the questionnaire research, the direct method used in similar studies (a general question about the quality assessment of a given type of service) was supplemented by an indirect method. Under this method, respondents were asked to answer detailed questions on each of the quality dimensions for the provision of municipal services indicated in Table 3. Respondents answered each question using a 5-point Likert scale ( 1 was the worst rating, and 5 was the best rating). In addition, respondents were asked about the use of new technologies.

To assure external validity, the research samples in each city were randomized (see Section 3.5. Data). To obtain the construct validity of the research questionnaire, we adopted a multi-step procedure of developing the research questionnaire. This procedure consisted of five essential steps as follows:

1. Preparation of the initial version of the questionnaire based on the study of the subject literature and the research experience of the authors;

2. Consultation of question content with academics specializing in research in the field of local government administration and the quality of services, as well as with the management staff at MOCs (see acknowledgments);

3. Development of an electronic questionnaire;

4. Pilot studies conducted on a non-random sample of people with a diverse demographic profile. The aim of the pilot was to test the research questionnaire. In particular, the comprehensibility of the questions and the accuracy of the suggested 
answers were checked. Additionally, in this stage, selected participants of the study were interviewed to provide insight into how they understood the questions and the process of answering;

5. Development of the final version of the research questionnaire.

In addition, to verify the reliability of the questionnaire, appropriate Cronbach's alpha [95] coefficients were calculated. In the case of questions about the quality of local public transport, the result was 0.897, and in the case of questions about the quality of waste management, it was 0.617 .

In the next stage of the study, average consumer satisfaction assessments for each dimension and an aggregated average for assessing the quality of both types of local public services under analysis were set. Subsequently, these values formed the basis for further analysis.

\subsection{Research Procedure}

Thus far, in the empirical research covering the relationship between the effectiveness of the functioning of enterprises and the quality of their services, authors used various statistical methods, many of which favor correlation analysis $[17,19,96]$ and regression analysis [20,97]. Therefore, in this study, correlation analysis and regression models were applied. In contrast to the previous studies, the variables in our analyses were of synthetic nature (i.e., they reflect the combined influence of various factors on efficiency and quality, respectively). These variables were determined based on the zero unitarization method (ZUM), which is usually used in the construction of aggregated rankings. As a result of this approach, Spearman's rank correlation method and univariate linear regression models were used to verify the research hypotheses.

The justification for the use of synthetic measures constructed on the basis of ZUM was the need to base on aggregated measures. It is because the aim of our research was not to examine the impact of various detailed variables determining the efficiency of MOCs on the quality of their services but to determine their relationship and possible interdependence. Such an approach is an important contribution to the literature, as it is an innovative attempt to aggregate performance and quality measures in various industries. The rationale for the creation of synthetic indicators is also the need for transparency and readability of the obtained results.

The first phase of the study compared the researched companies in local public transport and municipal waste management (see Section 2) in terms of the discussed factors that determined their operational, financial, and quality efficiency (Table 2). A multi-criteria ranking method was applied to make direct comparisons of the companies examined. To develop the rankings of analyzed companies, synthetic variables were used, which were based on ZUM [98].

The ZUM method consists of three main steps. In the first step, diagnostic variables $X_{j}$ are divided into stimulators, destimulators, and nominators. In the area of financial and operational efficiency, it was found that five of the variables tested were stimulators (the higher the value, the higher the efficiency), one variable was a destimulator (the lower the value, the higher the efficiency), and two were nominators (the greatest efficiency if the values are in a certain set). They comprised the following indicators:

- The stimulant in both types of analyzed companies included the following financial performance measures: return on net sales (ROS), return on equity (ROE), return on total assets (ROA), and rotation of assets (TAT). In addition, the stimulant was also a measure of operational efficiency. For local public transport, this was the intensity of the use of rolling stock and, in the case of municipal waste management, the level of recycling.

- $\quad$ Financial industry indicators were classified as destimulators. In local transport, it was the cost of making transport vehicles, and in the municipal economy, it was a synthetic cost indicator for obtaining a level of recycling. 
- The nominators in both types of analyzed companies were financial indicators: current liquidity, CR (desired nominal values $e$ in the range of $0.8-1.5$ ), and debt ratio, DR (desired nominal values e in the range of 40-67\%). The desired values forming the different ranges were determined according to the specificities of the industry concerned.

In the area of quality of service, it was found that nine of the characteristics in Table 3 were stimulators, and one feature was a destimulator. The following dimensions of the quality of the services provided were included in the stimulators: availability/complexity, frequency, punctuality/timeliness, safety, confidence, speed/efficiency, convenience, information, innovative technologies, and an overall assessment of the industry. The destimulator was the level of fees. In addition, the proportion of people using modern technologies was recognized as a nominator. In view of the natural limitations in this matter among the elderly, it was assumed that the optimal range for the indicated characteristic is from $30 \%$ to $70 \%$.

The second step of the ZUM method is to convert each of the analyzed variables into normalized variables $Z_{j}$ [99]. The normalizing formula for stimulators $(S)$ takes the form of

$$
z_{i j}=\frac{x_{i j}-\operatorname{minx}_{i}}{\max _{i} x_{i j}-\operatorname{minx}_{i}}, x_{j} \in S
$$

where $x_{i j}$-diagnostic variable $i$-th feature determining the efficiency for the $j$-th object, i.e., the municipal enterprise.

For destimulators $(D)$, this formula takes the form of

$$
z_{i j}=\frac{\max _{i j}-x_{i j}}{\max _{i} x_{i j}-\operatorname{minx}_{i} x_{i j}}, x_{j} \in D
$$

In the case of nominators $(N)$, when the range of nominal values of $\left\langle b_{1 j} ; b_{2 j}\right\rangle$ is known, the normalizing formula takes the form of

$$
z_{i j}=\left\{\begin{array}{c}
x_{i j}-\min _{i} x_{i j} \\
\frac{b_{1 j}-\min _{i} x_{i j}}{1} \text { when } \quad x_{i j}<b_{1 j} \\
1, \text { when } \quad x_{i j} \in\left[b_{1 j ;} ; b_{2 j}\right] \\
\frac{x_{i j}-\max _{i} x_{i j}}{b_{2 j}-\max _{i} x_{i j}}, \text { when } \quad x_{i j}>b_{2 j}, x_{j} \in N
\end{array}\right.
$$

The third step of the ZUM method involves the aggregation of normalized variables using arithmetic mean as follows:

$$
Q_{i}=\frac{1}{k} \sum_{j=1}^{k} z_{i j}
$$

The values of the synthetic variable $Q_{i}$ are normalized in the range $[0,1]$ and allow them to be ordered according to the intensity of the test phenomenon (respectively, efficiency or quality). The higher the value of variable $Q_{i}$ is achieved by a given object, the higher the position it occupies in the ranking of the test objects.

In the next stage of the study, based on the results of the ZUM method, two rankings of the surveyed companies were developed for both analyzed industries (local transport and waste management). For each industry, the first ranking was a multi-criteria assessment (using both financial efficiency measures and operational efficiency measures) that surveyed the financial and operational efficiency of the enterprises. The second ranking, on the other hand, covered the quality of the services provided by those enterprises. In order to examine whether the ordering (according to the multi-criteria ranking) of the financial and operational performance assessments of the companies examined was consistent with 
the order of quality assessments of these services, Spearman's rank correlation coefficients were calculated as follows:

$$
r_{s}=1-\frac{6 \sum_{i=1}^{n}\left(d_{x}-d_{y}\right)^{2}}{n\left(n^{2}-1\right)}
$$

where $d_{x}$-the numbers of the positions they occupy in the rankings of the quality of public services provided by the city concerned; $d_{y}$-the financial and operational efficiency of the enterprise operating in that city; $n$-number of enterprises surveyed.

The coefficient $r_{s}$ takes values from -1 to 1 . A positive value of Spearman's rank factor indicates compliance in the ordering of the examined objects. Obtaining a high positive value of this factor in the conducted study would, therefore, provide a basis for confirming the validity of the research hypotheses $\mathrm{H} 2$ and $\mathrm{H} 3$ (the level of financial and operational efficiency of municipal enterprise operations is associated with the level of quality of these services). A negative result would lead to the opposite conclusions (high financial and operational efficiency of municipal enterprises is associated with low quality of these services). On the other hand, a result hovering around zero would mean no direct link between financial and operational efficiency and the quality of the public services examined.

The final phase of the study included a linear regression analysis, which examined the extent to which the quality of services provided by MOCs influences their financial and operational efficiency. The study applied the basic linear regression model, which took the form of

$$
Q S_{i}=\beta_{0}+\beta_{1} F O E_{\mathrm{i} 1}
$$

where $Q S_{i}$ - a synthetic assessment obtained by means of ZUM of the quality of the services provided by the enterprise $i ; F O E_{i}$ - a synthetic assessment of the financial and operational efficiency of the enterprise $i\left(Q_{i}\right) ; \beta_{0}$-constant; $\beta_{1}$-directional coefficient.

The classic least squares test predicted the parameters of two regression models. The first model involved municipal enterprises providing local public transport services. The second model, on the other hand, included municipal waste management enterprises.

\subsection{Data}

The discussed methodology for examining the multi-level efficiency of municipal enterprises was used to examine the effectiveness of municipal enterprises operating in 11 largest Polish cities: Warsaw, Krakow, Poznan, Lodz, Gdansk, Wroclaw, Katowice, Lublin, Bydgoszcz, Bialystok, Rzeszow (which replaced Szczecin due to the availability of data) (Figure 2). As some cities had more than one MOC, the research sample included 16 local public transport companies and 12 municipal waste management companies. In 2019, these companies were monopolists or played a dominant role in the municipal economy of the selected cities.

The data necessary for the designation of the individual financial performance indicators of the MOC examined were obtained from a publicly available database maintained by the Ministry of Justice-National Court Register (www.ekrs.ms.gov.pl, accessed on 17 April 2021). This database publishes, among others, financial statements of all companies (commercial law companies) registered in Poland.

Secondary data published by the Chamber of Commerce for Urban Transport, which is an independent organization of carriers and passenger transport operators in Polish cities [100], were used to calculate the operational performance indicators of public transport companies (vehicle kilometers, vehicle hours). In addition, in order to obtain detailed information on the functioning of selected public transport enterprises, in September 2020, detailed questions were sent to the entities analyzed, regarding their functioning. Due to the public nature of the entities examined, questions were sent by way of a request for public information, which, by law, obliges public entities to provide information. The operational efficiency indicators of municipal waste management enterprises were calculated on the basis of data published in the official annual reports on the implementation of municipal waste management tasks in individual cities. 


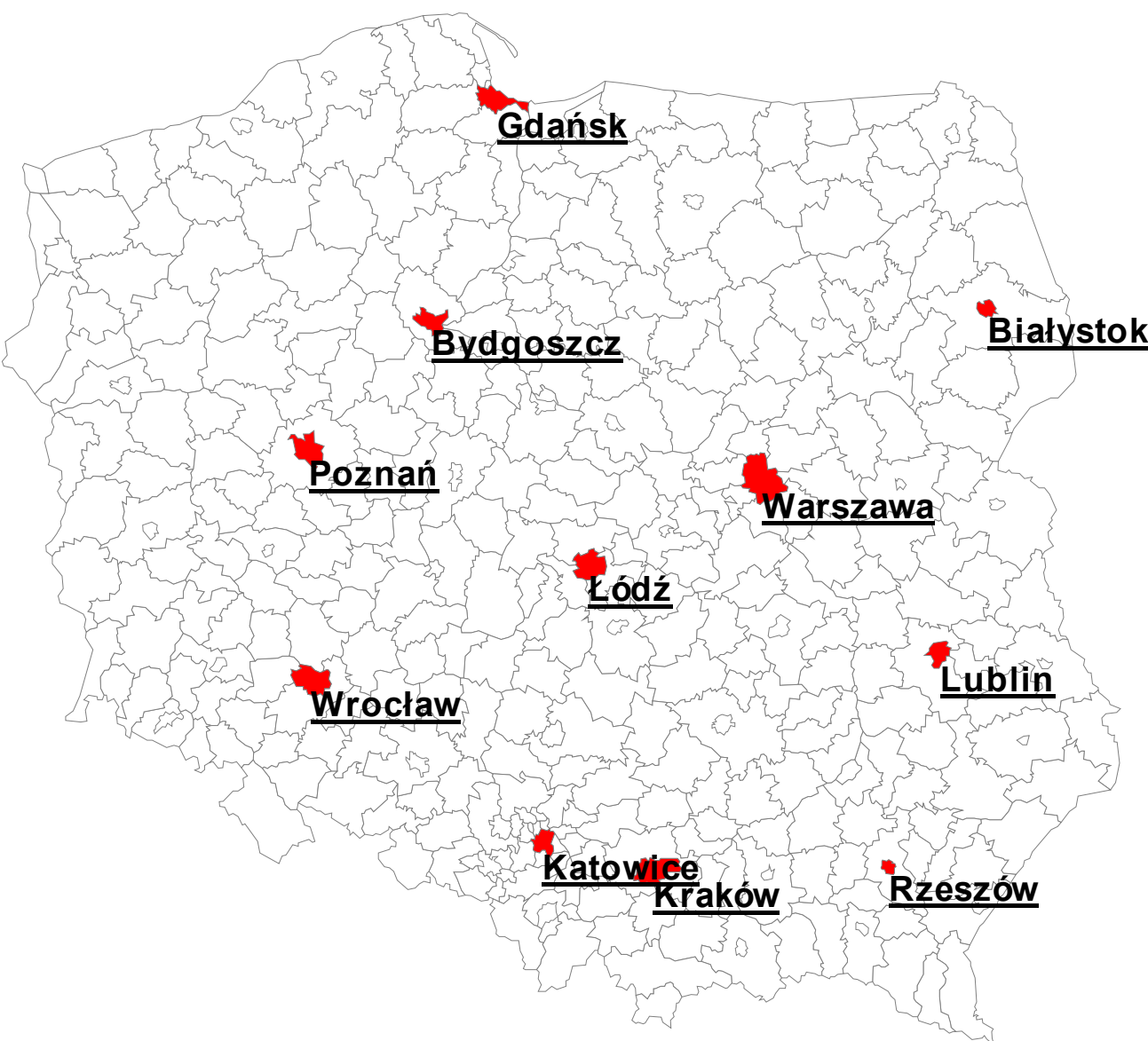

Figure 2. Cities covered in the study.

In order to obtain information on the quality of public services provided in the cities analyzed, original opinion surveys were carried out among the inhabitants of these cities. The study was conducted on a random sample of 1400 people, of whom 1247 gave complete responses (Table 4). The study was conducted using the computer-assisted web interview (CAWI) method, between September 2019 and December 2019.

Table 4. Structure of the research sample.

\begin{tabular}{lcc}
\hline Characteristics & Number of Responses & Share (\%) \\
\hline Total & 1247 & 100 \\
\hline Gender & & \\
$\quad$ woman & 641 & 51.40 \\
man & 606 & 48.60 \\
\hline Age & & \\
$18-24$ & 88 & 7.06 \\
$25-34$ & 215 & 17.24 \\
$35-44$ & 299 & 23.98 \\
$45-54$ & 297 & 23.82 \\
$55-64$ & 235 & 18.85 \\
$\quad>65$ & 113 & 9.05 \\
\hline Occupational status & & \\
working & 874 & 70.09 \\
entrepreneurs & 123 & 9.86 \\
out of work & 102 & 8.18 \\
pensioner & 148 & 11.87 \\
\hline
\end{tabular}


Table 4. Cont.

\begin{tabular}{lcc}
\hline Characteristics & Number of Responses & Share (\%) \\
\hline Education & 11 & \\
basic or professional & 74 & 0.88 \\
professional & 483 & 5.93 \\
averages & 679 & 38.74 \\
higher & & 54.45 \\
\hline Domicile & 199 & \\
single-family house & 129 & 15.96 \\
terraced house & 919 & 10.34 \\
multi-family construction & & 73.70 \\
\hline City of residence & 144 & \\
Warsaw & 140 & 11.55 \\
Krakow & 133 & 11.23 \\
Poznan & 107 & 10.67 \\
Lodz & 103 & 8.58 \\
Gdansk & 104 & 8.26 \\
Wroclaw & 101 & 8.34 \\
Katowice & 105 & 8.10 \\
Lublin & 100 & 8.42 \\
Bydgoszcz & 108 & 8.02 \\
Bialystok & 102 & 8.66 \\
Rzeszow & 8.17 \\
\hline
\end{tabular}

\section{Results}

The results regarding the financial and operational performance of the companies surveyed in accordance with the zero unitarization method (ZUM) are presented in Table 5. The table contains the ordered ranking according to the value of calculated synthetic variables $Q_{i}$, of MOCs providing local public transport (left side of the table) and MOCs providing municipal waste management (right side of the table). The source data used to calculate the value of $Q_{i}$ indicators for individual enterprises are given in Appendix A.

Table 5. Rankings of municipal enterprises surveyed in the area of financial and operational efficiency.

\begin{tabular}{|c|c|c|c|c|}
\hline \multirow{2}{*}{ Ranking } & \multicolumn{2}{|l|}{ Local Public Transport } & \multicolumn{2}{|l|}{ Municipal Waste Management } \\
\hline & Company Name (City) & $Q_{i}$ & Company Name (City) ${ }^{a}$ & $Q_{i}$ \\
\hline 1 & $\begin{array}{c}\text { Municipal Transport Company-Rzeszow } \\
\text { Ltd. (Rzeszow) }\end{array}$ & 0.8389 & $\begin{array}{c}\text { Service and Commercial and Production } \\
\text { Company “LECH” Ltd. in Bialystok } \\
\text { (Bialystok) }\end{array}$ & 0.7221 \\
\hline 2 & $\begin{array}{c}\text { Municipal Public Transport Company Ltd. in } \\
\text { Bialystok (Bialystok) }\end{array}$ & 0.8202 & REMONDIS Ltd. (Warsaw) & 0.7193 \\
\hline 3 & Warsaw Metro Ltd. (Warsaw) & 0.5946 & KOM-EKO PLC. (Lublin) & 0.7157 \\
\hline 4 & $\begin{array}{l}\text { Municipal Transport Company Lublin Ltd. } \\
\text { (Lublin) }\end{array}$ & 0.5785 & $\begin{array}{l}\text { ENERIS Ecological Disposal Centre Ltd. } \\
\text { (Poznan) }\end{array}$ & 0.6731 \\
\hline 5 & $\begin{array}{c}\text { Public Transport Company Katowice Ltd. } \\
\text { (Katowice) }\end{array}$ & 0.5745 & $\begin{array}{l}\text { Wroclaw Purification Company ALBA PLC } \\
\text { (Wroclaw) }\end{array}$ & 0.6712 \\
\hline 6 & $\begin{array}{c}\text { Municipal Transport Company JSC in } \\
\text { Krakow (Krakow) }\end{array}$ & 0.5737 & $\begin{array}{c}\text { City Municipal Economy Company Ltd. in } \\
\text { Katowice (Katowice) }\end{array}$ & 0.6431 \\
\hline 7 & Gdansk Buses and Trams Ltd. (Gdansk) & 0.5391 & Municipal Cleaning Company Ltd. (Krakow) & 0.5806 \\
\hline 8 & $\begin{array}{c}\text { Municipal Bus Company Ltd. in Warsaw } \\
\text { (Warsaw) }\end{array}$ & 0.4993 & Recycling Plant Ltd. in Gdansk (Gdansk) & 0.5661 \\
\hline 9 & $\begin{array}{c}\text { Municipal Transport Department Ltd. in } \\
\text { Bialystok (Bialystok) }\end{array}$ & 0.4989 & $\begin{array}{c}\text { City Municipal Economy } \\
\text { Company—Rzeszów Ltd. (Rzeszow) }\end{array}$ & 0.5648 \\
\hline
\end{tabular}


Table 5. Cont

\begin{tabular}{|c|c|c|c|c|}
\hline \multirow{2}{*}{ Ranking } & \multicolumn{2}{|l|}{ Local Public Transport } & \multicolumn{2}{|l|}{ Municipal Waste Management } \\
\hline & Company Name (City) & $Q_{i}$ & Company Name (City) ${ }^{a}$ & $Q_{i}$ \\
\hline 10 & Trams Warsaw Ltd. (Warsaw) & 0.4792 & ProNatura Ltd. (Bydgoszcz) & 0.56177 \\
\hline 11 & $\begin{array}{l}\text { Municipal Transport Company Ltd. in } \\
\text { Bialystok (Bialystok) }\end{array}$ & 0.4627 & $\begin{array}{l}\text { Municipal Cleaning Company Łódź Ltd. } \\
\text { (Lodz) }\end{array}$ & 0.5451 \\
\hline 12 & Silesian Trams PLC (Katowice) & 0.4372 & $\begin{array}{l}\text { Municipal Purification Company in Warsaw } \\
\text { Ltd. (Warsaw) }\end{array}$ & 0.2101 \\
\hline 13 & $\begin{array}{c}\text { Municipal Transport Company_—ódź Ltd. } \\
\text { (Lodz) }\end{array}$ & 0.4364 & - & - \\
\hline 14 & $\begin{array}{c}\text { Municipal Transport Company Ltd. in } \\
\text { Wroclaw (Wroclaw) }\end{array}$ & 0.4193 & - & - \\
\hline 15 & $\begin{array}{l}\text { Municipal Transport Company in Poznan Ltd. } \\
\text { (Poznan) }\end{array}$ & 0.3795 & - & - \\
\hline 16 & $\begin{array}{c}\text { Municipal Transport Facilities Ltd. in } \\
\text { Bydgoszcz (Bydgoszcz) }\end{array}$ & 0.3730 & - & - \\
\hline
\end{tabular}

${ }^{(a)}$ Formally, not all of the entities examined met all the criteria and the definition of MOCs (majority shares owned by local authorities). However, due to historical circumstances and the monopolistic or dominant position in the city concerned, it was decided to take them into account in the analysis.

The results of researching the quality of services provided in the cities where the examined MOCs operate are presented in Table 6. The source data used to calculate the values of the synthetic Qi city-specific indicators are in Appendix B.

Table 6. Rankings of municipal enterprises surveyed in the area of quality of services provided.

\begin{tabular}{ccccc}
\hline \multirow{2}{*}{ Ranking } & \multicolumn{2}{c}{ Local Public Transport } & \multicolumn{2}{c}{ Municipal Waste Management } \\
& City & $\boldsymbol{Q}_{\boldsymbol{i}}$ & City & $\boldsymbol{Q}_{\boldsymbol{i}}$ \\
\hline 1 & Warsaw & 0.6971 & Bialystow & 0.8174 \\
2 & Krakow & 0.6786 & Wroclaw & 0.7948 \\
3 & Poznan & 0.6450 & Krakow & 0.7161 \\
4 & Katowice & 0.6108 & Gdansk & 0.7156 \\
5 & Gdansk & 0.6076 & Rzeszow & 0.6256 \\
6 & Rzeszow & 0.6040 & Poznan & 0.5825 \\
7 & Wroclaw & 0.5420 & Lodz & 0.5670 \\
8 & Lublin & 0.5306 & Warsaw & 0.5486 \\
9 & Bydgoszcz & 0.5125 & Bydgoszcz & 0.5474 \\
10 & Bialystok & 0.5078 & Lublin & 0.5457 \\
11 & Lodz & 0.3708 & Katowice & 0.4607 \\
\hline
\end{tabular}

When analyzing the results obtained, it should be stressed that they take into account the study of the quality of services provided by MOCs operating in a given city and not the quality of services provided by the MOCs concerned. This is important because for some cities services in a given area are provided by more than one MOC (e.g., in Warsaw, transport services are provided by three MOCs). The focus on analyzing the quality of services provided in a given city was due to methodological limitations. The pilot studies showed that without knowing that more than one operator was providing the service in question, residents were not able to differentiate their quality at the level of specific enterprises. If there were several MOCs in the city concerned, this approach, therefore, resulted in the quality assessment obtained being the result of the result for all these entities. In the following stages, where the study focused on the relationship between the financial and operational efficiency of MOCs and the quality of their services, each of the entities surveyed was assigned an assessment of the quality of services provided in a given city. 
The relationship between financial and operational efficiency and the quality of services provided by the MOCs analyzed is presented in Figures 3 and 4. The general conclusion from the analysis of the two figures suggests that there is no link between the variables studied. This observation is confirmed by the results of the correlation analysis. For MOCs providing local public transport, the $r_{s}$ factor was 0.1610 and statistically insignificant $\left(p\right.$-value $=0.5328$ ). For municipal waste MOCs, an $r_{s}$ factor of 0.4633 suggests a moderate interdependence of the variables tested. However, this value is statistically insignificant ( $p$-value $=0.1244$, which makes it impossible to draw binding conclusions in this area. In conclusion, the results of the correlation analysis show that the consistency of the order (rankings) of financial and operational efficiency, and the quality of services of the companies surveyed is low. This observation is an argument against $\mathrm{H} 2$ and $\mathrm{H} 3$ hypotheses.

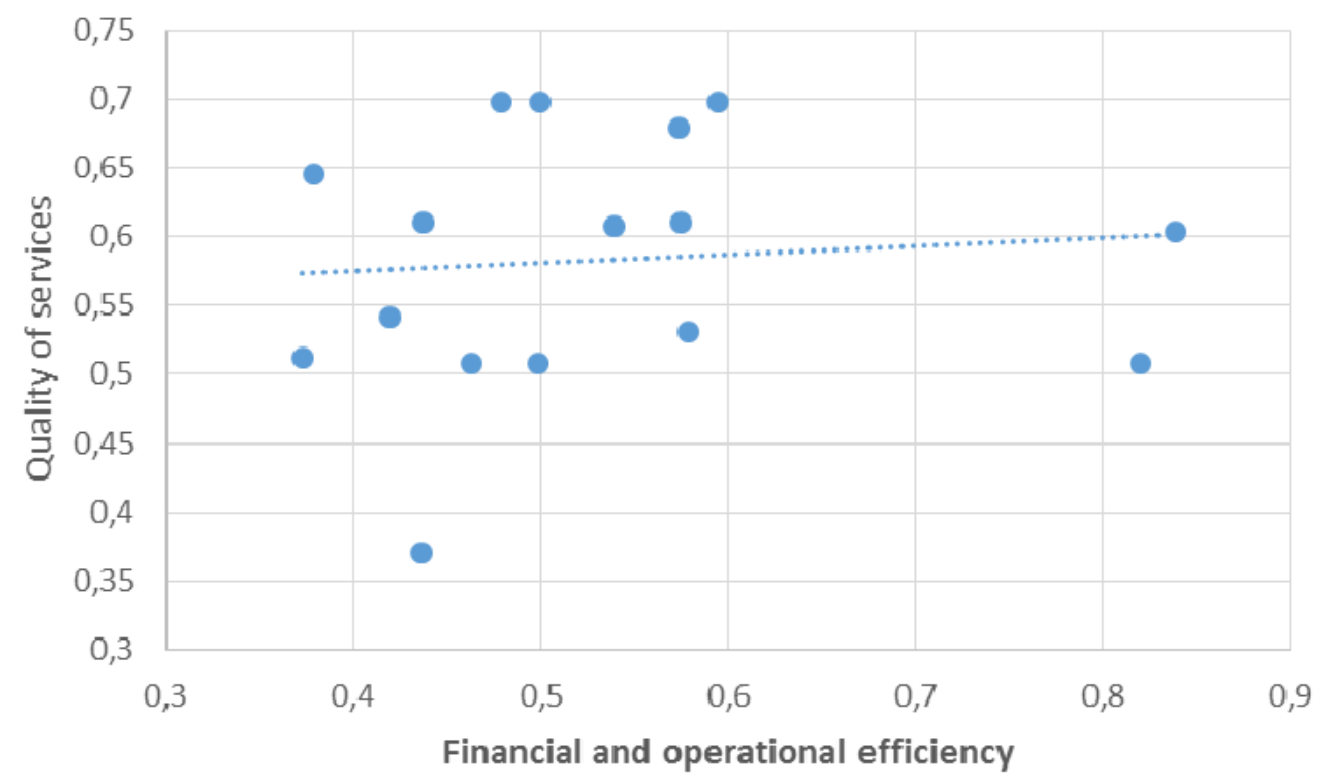

Figure 3. Scattering graph of variables tested for local public transport MOCs.

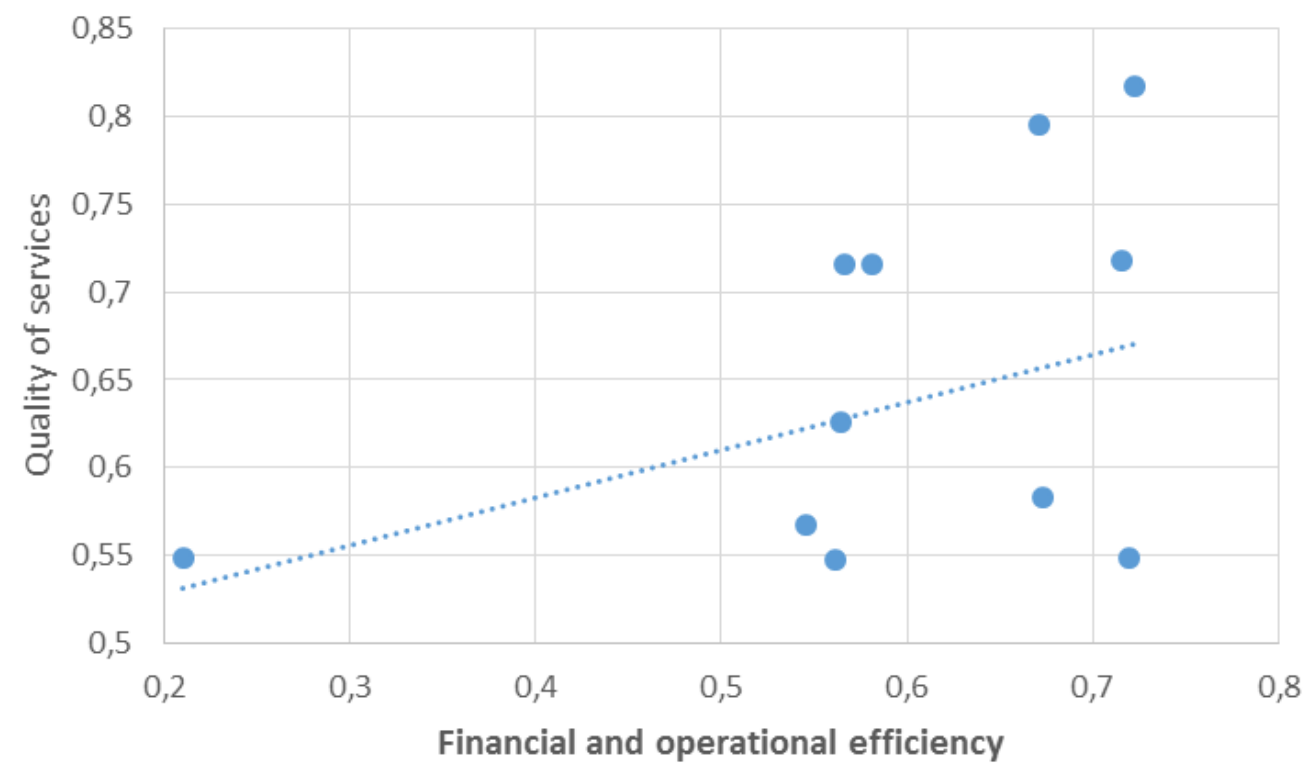

Figure 4. Scattering graph of variables tested for municipal waste management MOCs. 
The hypothesis of the existence of a positive relationship between financial and operational effectiveness with the quality of services provided by MOCs is also challenged by the conclusions formulated based on regression analysis (Table 7).

Table 7. Relationship between financial and operational effectiveness and the quality of services provided by MOCs according to the line regression model.

\begin{tabular}{|c|c|c|c|c|c|}
\hline Parameter & Coefficient & Standard Error & 95\% Confidence Interval & t Statistic & $p$-Value \\
\hline \multicolumn{6}{|c|}{ MOCs providing local public transport services } \\
\hline (Constant) & 0.5506 & 0.0985 & {$[0.3394 ; 0.7619]$} & 5.5904 & 0.0001 \\
\hline Financial and operational efficiency (FOE) & 0.0608 & 0.1799 & {$[-0.3250 ; 0.4466]$} & 0.3379 & 0.7404 \\
\hline R-squared & 0.0081 & - & - & - & - \\
\hline Adjusted R-squared & -0.0628 & - & - & - & - \\
\hline $\begin{array}{l}\text { Overall model significance } \\
\qquad \text { (F- } p \text {-value test })\end{array}$ & 0.7404 & - & - & - & - \\
\hline \multicolumn{6}{|c|}{ MOCs providing municipal waste management } \\
\hline (Constant) & 0.4737 & 0.1469 & {$[0.1463 ; 0.8011]$} & 3.2234 & 0.0091 \\
\hline Financial and operational efficiency (FOE) & 0.2729 & 0.2399 & {$[-0.2616 ; 0.8075]$} & 1.1376 & 0.2818 \\
\hline R-squared & 0.1146 & - & - & - & - \\
\hline Adjusted R-squared & 0.0260 & - & - & - & - \\
\hline $\begin{array}{l}\text { Overall model significance } \\
\quad(\mathrm{F}-p \text {-value test })\end{array}$ & 0.2818 & - & - & - & - \\
\hline
\end{tabular}

The estimated values of regression model parameters for MOCs providing local public transport services and municipal waste management MOCs indicate that operational efficiency does not affect the quality of services provided by the enterprises analyzed. In both estimated models, the $\beta$ coefficients, indicating how a change in quality is affected by a change in financial and operational efficiency, were statistically insignificant. Moreover, when interpreting the results obtained, attention should also be paid to the low degree of fit of both models (adjusted R2) and their overall statistical insignificance (F-test $p$-value).

\section{Conclusions and Discussion}

As a result of our analysis, we rejected both detailed research hypotheses ( $\mathrm{H} 2$ and $\mathrm{H} 3$ ). The analyses carried out support the claim that, as measured by the indicators of operational and financial efficiency of municipal undertakings providing local public transport services, there is no correlation to the perceived quality of the services they provide to residents. Similarly, the efficiency of municipal enterprises providing municipal waste management services does not in any way translate into the quality of those services perceived by the residents. Both of these observations warrant the rejection of the main research hypothesis (H1). This means that the financial and operational efficiency of municipal enterprises is not associated with the quality of the services they provide.

It is difficult to relate the results of our research to other analyses because an attempt to assess the correlation between the operational and financial efficiency of public service providers and the quality of these services has not yet been undertaken. In the light of our considerations, this is surprising since the question of this relationship should be of fundamental importance in choosing how to provide municipal services. Previous studies have usually attempted to analyze the effectiveness of different models of public service provision in terms of ownership (public or private entity) or organizational (local bureaucracy versus corporations) [9].

In the scant research addressing the effectiveness of MOCs, the activities of these entities were mainly juxtaposed against the functioning of local bureaucracy in aspects such as failure rates, financial efficiency, cost efficiency, and labor costs [9]. Some studies also analyzed and compared the effectiveness of MOCs operating in different industries [22,25], as well as the effectiveness of singular MOCs (owned by a single locality) and joint MOCs (owned by several localities) $[9,23,71]$. Even less frequently, studies were undertaken on 
the quality of services provided by MOCs. In examining the satisfaction with the services of MOCs, Cuadrado-Ballesteros, García-Sánchez, and Prado-Lorenzo [22] found that in all industries MOCs provide a higher quality of life than the local bureaucracy.

Contrary to previous studies, in this study, we did not compare the effectiveness of MOCs or the quality of their services with other forms of public service delivery. Instead, we focused on a different aspect of MOC functioning - we tried to verify whether there is a link between the financial objectives and the quality aspect of the services provided. The financial objectives are set for each undertaking in the competitive market. The quality of services, access to which determines the comfort of the life of every citizen, defines and constitutes the functioning of MOCs.

Although the studies carried out relate to Poland, their results are also useful on a global and, in particular, European scale. Theoretical considerations show that the analysis of MOCs limited only to the financial and operational aspects is incomplete and inadequate to the role currently played by the provision of services of general interest. In addition to efficiency, the quality of the services they provide depends on meeting the expectations of consumer-citizens and is a key determinant of the assessment of the functioning of MOCs. From the empirical analysis, it emerges that the financial and operational efficiency of MOCs does not translate into the quality of the services they provide. The objective of rational management in MOCs must therefore be to both increase financial efficiency and improve the quality of life of citizens using their services. This requires that other criteria for measuring the quality of meeting the needs of the local community be taken into account in the assessment of MOC activities, in addition to financial criteria.

Our research is part of a discussion already launched in the 1970s at the Strategic Planning Institute in Cambridge, USA, on the relationship between the quality of the products and services offered and the financial efficiency of the enterprise [101]. Today, this discussion is also continued by authors from European and Asian countries. It mainly concerns financial market entities, such as banks ([20,102]), new technology enterprises ([21]), service companies ([19]), as well as the health sector $([17,96,97])$. The main result of these studies is the widespread belief that in a market economy, enterprises selling high-quality products and services are generally more profitable than competitors offering lower quality standards. Thus, in the modern economy, simple efficiency optimization is not adequate to ensure the successful operation of an enterprise. To be able to compete, entities should consider also external factors, such as the quality of the services provided. In this context, Zervopoulos and Palaskas [103] support the view that simultaneous assessment of both efficiency and quality is necessary. Our research broadens the scope of this discussion to an analysis of the relationship in question in MOCs, which provide a specific type of service and have a public owner (or co-owner). Our analysis shows that, unlike typical market players, this relationship does not exist in MOCs.

With regard to our research into the broader context, we point out that they are part of a broader discussion on the recommunalization of public services [6-8]. The trend, observed in many countries, is now to replace the privatization of the provision of public services that was dominant until the 1990s with a model in which these services are provided by municipal entities, including MOCs. This change is due to the observation that the cost criterion (financial efficiency) highlighted earlier is not the most important from the point of view of the provision of these services. For citizen-consumers, the quality of these services is more important and tangible, which is reflected in characteristics such as universality, accessibility, comfort, reliability, or cost of use. In other words, the average citizen is more interested in the frequency and timeliness of collecting his/her rubbish than the financial result of the company involved. On the other hand, at the level of the general public today, it is more important to demand sustainable development (e.g., recycling of waste) through MOCs than to maximize their profitability. The main distinguishing feature of the activities of those entities is the assumption of the paramount importance of the quality criterion in assessing their functioning. 
The main limitation of the research carried out was the number of MOCs tested. However, the selection of MOCs for the study was subject to three objective limitations. Firstly, in most Polish cities, there is one MOC in the industries analyzed. Secondly, it is difficult for studies in smaller localities to have the detailed data necessary to assess the effectiveness of MOCs. Thirdly, conducting research in more localities would require a significant increase in the survey sample. From a methodological point of view, the research limitation concerns our aggregated approach - this approach enabled a comprehensive (synthetic) assessment of the effectiveness of MOCs and the quality of their services, but on the other hand, it omitted certain nuances of the activities of the companies concerned.

The studies carried out may form the basis for further in-depth analyses. In particular, it is desirable to carry out analyses on a larger sample of MOCs and in other sectors of public service provision. It is also a natural extension of our research to carry out international comparisons. From a methodological perspective on interesting conclusions, the method we have proposed could be used outside the area of public service provision - in the area of market enterprises. On the other hand, given the limitations of our research method, it is desirable to improve the ways in which financial and operational efficiency and quality of services provided by MOCs are measured. No less important are studies involving the identification and evaluation of the impact of various factors on the effectiveness of MOCs and the quality of their services.

Author Contributions: Conceptualization, T.J. and K.W.; methodology, T.J. and K.W.; validation, T.J. and K.W; formal analysis, T.J. and K.W.; investigation, T.J. and K.W.; resources, T.J. and K.W.; data curation, T.J. and K.W.; writing-original draft preparation, T.J. and K.W.; writing-review and editing, T.J. and K.W.; visualization, T.J. and K.W.; supervision, T.J. and K.W.; project administration, T.J. and K.W.; funding acquisition, T.J. and K.W. All authors have read and agreed to the published version of the manuscript.

Funding: This project has been financed by the Ministry of Science and Higher Education within the 'Regional Initiative of Excellence' Program for 2019-2022. Project no.: 021/RID/2018/19. Total financing: 11897 131.40 PLN.

Institutional Review Board Statement: Not applicable.

Informed Consent Statement: Informed consent was obtained from all subjects involved in the study.

Data Availability Statement: Not applicable.

Acknowledgments: This research is part of the project-Rev 4.0-Socio-economic Consequences of the Fourth Industrial Revolution (2019-2022), the key research area: Models of public goods and services production and distribution. We would like to express our gratitude to the research team led by prof. Maria Płonka, to whom we belong, for valuable comments and insightful opinions in our research.

Conflicts of Interest: The authors declare no conflict of interest.

\section{Appendix A}

Table A1. Financial and operational performance indicators of local public transport MOCs tested.

\begin{tabular}{|c|c|c|c|c|c|c|c|c|c|}
\hline $\begin{array}{c}\text { Full Name of Municipally Owned } \\
\text { Corporation }\end{array}$ & City & $\begin{array}{c}\text { ROS } \\
(\%)\end{array}$ & $\begin{array}{c}\mathrm{ROE} \\
(\%)\end{array}$ & $\begin{array}{c}\text { ROA } \\
(\%)\end{array}$ & TAT & CR & $\begin{array}{l}\text { DR } \\
(\%)\end{array}$ & $\begin{array}{c}C V K \\
(\text { PLN/vkm) }\end{array}$ & $\begin{array}{c}V U I \\
(\mathrm{vkm} / \mathrm{vh})\end{array}$ \\
\hline $\begin{array}{l}\text { Municipal Public Transport } \\
\text { Company Ltd. in Bialystok }\end{array}$ & Bialystok & -1.35 & -2.66 & -1.76 & 131 & 3.18 & 33.82 & 7.95 & 16.48 \\
\hline $\begin{array}{l}\text { Municipal Transport Company Ltd. } \\
\text { in Bialystok }\end{array}$ & Bialystok & 2.27 & 12.32 & 5.24 & 2.31 & 1.45 & 57.50 & 9.50 & 15.89 \\
\hline $\begin{array}{l}\text { Municipal Communication } \\
\text { Department Ltd. in Bialystok }\end{array}$ & Bialystok & -1.35 & -2.81 & -2.01 & 1.49 & 2.00 & 28.21 & 7.24 & 15.88 \\
\hline $\begin{array}{l}\text { Municipal Transport Facilities Ltd. } \\
\text { in Bydgoszcz }\end{array}$ & Bydgoszcz & -8.37 & -14.83 & -9.70 & 1.16 & 1.38 & 34.60 & 8.04 & 16.32 \\
\hline Gdansk Buses and Trams Ltd. & Gdansk & 0.81 & 2.39 & 0.49 & 0.61 & 1.32 & 79.37 & 11.79 & 16.63 \\
\hline
\end{tabular}


Table A1. Cont.

\begin{tabular}{|c|c|c|c|c|c|c|c|c|c|}
\hline $\begin{array}{c}\text { Full Name of Municipally Owned } \\
\text { Corporation }\end{array}$ & City & $\begin{array}{c}\text { ROS } \\
(\%)\end{array}$ & $\begin{array}{c}\text { ROE } \\
(\%)\end{array}$ & $\begin{array}{c}\text { ROA } \\
(\%)\end{array}$ & TAT & CR & $\begin{array}{l}\text { DR } \\
(\%)\end{array}$ & $\begin{array}{c}\text { CVK } \\
\text { (PLN/vkm) }\end{array}$ & $\begin{array}{c}\text { VUI } \\
(\mathrm{vkm} / \mathrm{vh})\end{array}$ \\
\hline $\begin{array}{l}\text { Public Transport Company } \\
\text { Katowice Ltd. }\end{array}$ & Katowice & -2.15 & -4.95 & -2.01 & 0.94 & 1.72 & 59.41 & 8.28 & 15.99 \\
\hline Silesian Trams PLC. & Katowice & 0.54 & 0.71 & 0.12 & 0.23 & 1.03 & 82.77 & 13.79 & 14.00 \\
\hline $\begin{array}{l}\text { Municipal Transport Company JSC } \\
\text { in Krakow }\end{array}$ & Krakow & 1.30 & 1.70 & 0.56 & 0.43 & 1.92 & 67.26 & 11.70 & 14.95 \\
\hline $\begin{array}{l}\text { Municipal Transport Company } \\
\text { Lublin Ltd. }\end{array}$ & Lublin & -0.13 & -0.39 & -0.12 & 0.96 & 0.86 & 68.47 & 11.53 & 13.86 \\
\hline $\begin{array}{l}\text { Municipal Transport } \\
\text { Company-Lodz Ltd. }\end{array}$ & Lodz & 0.13 & 0.63 & 0.09 & 0.68 & 0.90 & 85.79 & 13.44 & 14.08 \\
\hline $\begin{array}{l}\text { Municipal Transport Company in } \\
\text { Poznan Ltd. }\end{array}$ & Poznan & -2.35 & -2.13 & -0.73 & 0.31 & 0.49 & 65.61 & 13.36 & 14.80 \\
\hline $\begin{array}{l}\text { Municipal Transport } \\
\text { Company-Rzeszow Ltd. }\end{array}$ & Rzeszow & 1.87 & 10.30 & 5.90 & 3.15 & 1.12 & 42.73 & 10.41 & 16.37 \\
\hline $\begin{array}{l}\text { Municipal Bus Companies Ltd. in } \\
\text { Warsaw }\end{array}$ & Warsaw & 0.05 & 0.07 & 0.05 & 1.04 & 1.33 & 26.91 & 10.67 & 15.70 \\
\hline Trams Warsaw Ltd. & Warsaw & 1.41 & 1.02 & 0.34 & 0.24 & 2.10 & 66.94 & 16.45 & 14.00 \\
\hline Warsaw Metro Ltd. & Warsaw & 2.28 & 1.79 & 0.83 & 0.36 & 3.35 & 53.64 & 12.55 & 28.84 \\
\hline $\begin{array}{l}\text { Municipal Transport Company Ltd. } \\
\text { in Wroclaw }\end{array}$ & Wroclaw & -2.17 & -5.34 & -0.92 & 0.42 & 1.69 & 82.79 & 9.98 & 14.33 \\
\hline
\end{tabular}

Table A2. Financial and operational performance indicators of municipal waste MOCs tested.

\begin{tabular}{|c|c|c|c|c|c|c|c|c|c|}
\hline $\begin{array}{l}\text { Full Name of Municipally Owned } \\
\text { Corporation }\end{array}$ & City & $\begin{array}{c}\text { ROS } \\
(\%)\end{array}$ & $\begin{array}{l}\mathrm{ROE} \\
(\%)\end{array}$ & $\begin{array}{c}\text { ROA } \\
(\%)\end{array}$ & TAT & CR & $\begin{array}{l}\text { DR } \\
(\%)\end{array}$ & $\begin{array}{c}R C \\
\text { (p.p.u. } / \%) *\end{array}$ & $\begin{array}{l}L R \\
(\%)\end{array}$ \\
\hline Service and Commercial and & & & & & & & & & \\
\hline $\begin{array}{l}\text { Production Company “LECH” Ltd. } \\
\text { in Bialystok }\end{array}$ & Bialystok & 9.21 & 10.79 & 1.87 & 0.2 & 0.59 & 82.67 & 693.22 & 59 \\
\hline ProNatura Ltd. & Bydgoszcz & 5.32 & 9.29 & 4.57 & 0.86 & 0.42 & 50.78 & 1502.76 & 44 \\
\hline Disposal Plant Ltd. in Gdansk & Gdansk & -6.01 & -4.81 & -1.62 & 0.27 & 0.44 & 66.41 & 776.42 & 50 \\
\hline $\begin{array}{l}\text { City Municipal Economy Company Ltd. } \\
\text { in Katowice }\end{array}$ & Katowice & 1.07 & 0.99 & 0.61 & 0.57 & 0.5 & 38.86 & 806.11 & 42 \\
\hline Municipal Cleaning Company Ltd. & Krakow & 1.24 & 4.88 & 1.67 & 1.34 & 0.42 & 65.76 & 1786.33 & 39 \\
\hline KOM-EKO PLC. & Lublin & 3.72 & 10.53 & 3.47 & 0.93 & 0.39 & 67 & 1381.48 & 30 \\
\hline $\begin{array}{l}\text { Municipal Cleaning Company } \\
\text { Lodz Ltd. }\end{array}$ & Lodz & -0.68 & -5.38 & -0.98 & 1.45 & 0.3 & 81.78 & 1227.15 & 44 \\
\hline ENERIS Ecological Disposal Center Ltd. & Poznan & 5.94 & 17.7 & 5.13 & 0.86 & 0.41 & 70.99 & 1323.17 & 41 \\
\hline $\begin{array}{l}\text { City Municipal Economy } \\
\text { Company_Rzeszow Ltd. }\end{array}$ & Rzeszow & -7.32 & -64.65 & -18.35 & 2.51 & 0.59 & 71.61 & 1296.16 & 59 \\
\hline $\begin{array}{l}\text { Municipal Purification Company in } \\
\text { Warsaw Ltd. }\end{array}$ & Warsaw & -40.16 & -53.07 & -17.65 & 0.44 & 0.42 & 66.75 & 1811.84 & 42 \\
\hline REMONDIS Ltd. & Warsaw & 6.33 & 7.58 & 1.43 & 0.23 & 0.42 & 81.14 & 1187.22 & 42 \\
\hline $\begin{array}{l}\text { Wroclaw Cleaning Company } \\
\text { ALBA PLC. }\end{array}$ & Wroclaw & -1.99 & -9.17 & -3.48 & 1.74 & 0.44 & 62.1 & 1631.16 & 42 \\
\hline
\end{tabular}




\section{Appendix B}

Table A3. Quality of service tested MOCs offering local public transport.

\begin{tabular}{|c|c|c|c|c|c|c|c|c|c|c|c|c|}
\hline $\begin{array}{c}\text { City/ } \\
\text { Quality } \\
\text { Standards }\end{array}$ & $\begin{array}{l}\text { Availability } \\
\text { of the Com- } \\
\text { munication } \\
\text { Network }\end{array}$ & $\begin{array}{l}\text { Frequency } \\
\text { of Running }\end{array}$ & $\begin{array}{c}\text { Punctuality } \\
\text { of the } \\
\text { Transport }\end{array}$ & $\begin{array}{l}\text { Travel } \\
\text { Safety }\end{array}$ & $\begin{array}{c}\text { The certainty } \\
\text { of a Planned } \\
\text { Trip }\end{array}$ & $\begin{array}{l}\text { Immediacy } \\
\text { and Speed } \\
\text { of Travel }\end{array}$ & $\begin{array}{c}\text { The Conve- } \\
\text { nience of } \\
\text { Travel }\end{array}$ & $\begin{array}{c}\text { Information } \\
\text { about the } \\
\text { Transport Offer }\end{array}$ & $\begin{array}{c}\text { Use of } \\
\text { Innovative } \\
\text { Technologies }\end{array}$ & Cost & $\begin{array}{c}\text { Percentage of } \\
\text { Users of Modern } \\
\text { Technologies }(\%)\end{array}$ & $\begin{array}{l}\text { Overall } \\
\text { Rating }\end{array}$ \\
\hline Bialystok & 3.86 & 3.49 & 3.71 & 3.47 & 3.48 & 3.80 & 3.66 & 3.93 & 3.70 & 4.28 & 46.33 & 3.69 \\
\hline Gdansk & 3.96 & 3.59 & 3.59 & 3.59 & 3.40 & 3.55 & 3.55 & 4.05 & 3.86 & 4.03 & 55.00 & 3.63 \\
\hline Katowice & 3.79 & 3.65 & 3.58 & 3.60 & 3.54 & 3.72 & 3.64 & 4.02 & 3.78 & 4.10 & 52.33 & 3.60 \\
\hline Krakow & 3.96 & 3.58 & 3.70 & 3.55 & 3.50 & 3.56 & 3.60 & 4.03 & 3.82 & 3.94 & 54.33 & 3.61 \\
\hline Lublin & 3.89 & 3.58 & 3.55 & 3.68 & 3.48 & 3.67 & 3.59 & 4.00 & 3.69 & 4.23 & 47.67 & 3.54 \\
\hline Lodz & 3.72 & 3.57 & 3.62 & 3.57 & 3.41 & 3.69 & 3.48 & 3.97 & 3.67 & 4.21 & 50.00 & 3.56 \\
\hline Rzeszow & 3.77 & 3.70 & 3.52 & 3.69 & 3.53 & 3.67 & 3.68 & 3.87 & 3.74 & 4.00 & 45.00 & 3.53 \\
\hline Warsaw & 3.99 & 3.60 & 3.75 & 3.56 & 3.47 & 3.85 & 3.47 & 3.92 & 3.79 & 3.86 & 57.33 & 3.59 \\
\hline Wroclaw & 3.78 & 3.66 & 3.64 & 3.54 & 3.49 & 3.60 & 3.62 & 3.84 & 3.79 & 4.03 & 52.67 & 3.64 \\
\hline
\end{tabular}

Table A4. Quality of service of tested MOCs dealing with municipal waste management.

\begin{tabular}{|c|c|c|c|c|c|c|c|c|c|c|c|c|}
\hline $\begin{array}{c}\text { City/ } \\
\text { Quality } \\
\text { Standards }\end{array}$ & $\begin{array}{c}\text { Comprehensive } \\
\text { Collection }\end{array}$ & $\begin{array}{c}\text { Frequency } \\
\text { of Collection }\end{array}$ & $\begin{array}{c}\text { Timely } \\
\text { Collection }\end{array}$ & $\begin{array}{l}\text { Certainty of } \\
\text { Waste } \\
\text { Collection }\end{array}$ & $\begin{array}{c}\text { Ease of } \\
\text { Waste } \\
\text { Segregation }\end{array}$ & $\begin{array}{c}\text { Winter } \\
\text { Infrastructure } \\
\text { Maintenance }\end{array}$ & $\begin{array}{c}\text { Ease of } \\
\text { Segregation }\end{array}$ & $\begin{array}{c}\text { Information about } \\
\text { the Waste } \\
\text { Collection Offer }\end{array}$ & $\begin{array}{c}\text { Use of } \\
\text { Modern } \\
\text { Technologies }\end{array}$ & Cost & $\begin{array}{c}\text { Percentage of } \\
\text { Users of Modern } \\
\text { Technologies (\%) }\end{array}$ & $\begin{array}{l}\text { Overall } \\
\text { Rating }\end{array}$ \\
\hline Bialystok & 3.4 & 3.04 & 3.82 & 3.9 & 3.79 & 3.53 & 3.25 & 3.21 & 3.17 & 4.13 & 39.43 & 3.37 \\
\hline Bydgoszcz & 3.28 & 3.01 & 3.74 & 3.86 & 3.64 & 3.40 & 3.29 & 3.13 & 3.05 & 4.04 & 41.43 & 3.02 \\
\hline Gdansk & 3.34 & 2.99 & 3.74 & 3.63 & 3.76 & 3.48 & 3.40 & 3.25 & 3.08 & 4.11 & 37.00 & 3.21 \\
\hline Katowice & 3.28 & 3.03 & 3.69 & 3.62 & 3.66 & 3.36 & 3.33 & 3.16 & 3.06 & 4.09 & 38.29 & 3.07 \\
\hline Krakow & 3.33 & 3.05 & 3.82 & 3.86 & 3.82 & 3.53 & 3.26 & 3.22 & 3.18 & 4.14 & 33.86 & 3.18 \\
\hline Lublin & 3.30 & 3.00 & 3.67 & 3.72 & 3.75 & 3.41 & 3.30 & 3.08 & 3.04 & 4.04 & 37.43 & 3.21 \\
\hline Lodz & 3.24 & 2.90 & 3.75 & 3.56 & 3.72 & 3.36 & 3.32 & 3.19 & 3.12 & 4.07 & 35.14 & 3.12 \\
\hline Poznan & 3.29 & 2.97 & 3.64 & 3.70 & 3.70 & 3.47 & 3.36 & 3.15 & 3.04 & 4.11 & 35.71 & 3.05 \\
\hline Rzeszow & 3.28 & 2.98 & 3.73 & 3.82 & 3.71 & 3.48 & 3.31 & 3.14 & 3.04 & 4.05 & 40.00 & 3.12 \\
\hline Wroclaw & 3.36 & 3.02 & 3.77 & 3.65 & 3.75 & 3.50 & 3.42 & 3.26 & 3.11 & 4.07 & 39.43 & 3.33 \\
\hline
\end{tabular}




\section{References}

1. Weimer, D.L.; Vining, A.R. Policy Analysis: Concepts and Practice, 6th ed.; Routledge: Milton Park, UK, 2017; ISBN 978-1-138-21651-8.

2. Nowotny, K. The Economics of public utility regulation: An overview. In Public Utility Regulation: The Economic and Social Control of Industry. Recent Economic Thought Series; Nowotny, K., Smith, D.B., Trebing, H.M., Eds.; Springer: Dordrecht, The Netherlands, 1989; pp. 9-27, ISBN 978-94-009-2508-3.

3. Baek, S.; Kim, S. Participatory public service design by Gov.3.0 Design Group. Sustainability 2018, 10, 245. [CrossRef]

4. Esposito, P.; Dicorato, S.L.; Doronzo, E. The effect of ownership on sustainable development and environmental policy in urban waste management: An explicatory empirical analysis of Italian municipal corporations. Bus. Strat. Environ. 2020, 30, 1067-1079. [CrossRef]

5. Parker, D. Regulating public utilities: Lessons from the UK experience. Int. Rev. Adm. Sci. 1999, 65, 117-131. [CrossRef]

6. Becker, S.; Beveridge, R.; Naumann, M. Remunicipalization in German cities: Contesting neo-liberalism and reimagining urban governance? Space Polity 2015, 19, 76-90. [CrossRef]

7. Wagner, O.; Berlo, K. Remunicipalisation and foundation of municipal utilities in the german energy sector: Details about newly established enterprises. J. Sustain. Dev. Energy Water Environ. Syst. 2017, 5, 396-407. [CrossRef]

8. Cumbers, A.; Becker, S. Making sense of remunicipalisation: Theoretical reflections on and political possibilities from Germany'sRekommumalisierungprocess. Camb. J. Reg. Econ. Soc. 2018, 11, 503-517. [CrossRef]

9. Voorn, B.; Van Genugten, M.L.; Van Thiel, S. The efficiency and effectiveness of municipally owned corporations: A systematic review. Local Gov. Stud. 2017, 43, 820-841. [CrossRef]

10. Tavares, A.F. Ten years after: Revisiting the determinants of the adoption of municipal corporations for local service delivery. Local Gov. Stud. 2017, 43, 697-706. [CrossRef]

11. Narmania, D. Efficient management of municipal enterprises. Eur. J. Multidiscip. Stud. 2018, 7, 76-79. [CrossRef]

12. Bergh, A.; Erlingsson, G.; Gustafsson, A.; Wittberg, E. Municipally owned enterprises as danger zones for corruption? How politicians having feet in two camps may undermine conditions for accountability. Public Integr. 2018, 21, 320-352. [CrossRef]

13. Andrews, R.; Ferry, L.; Skelcher, C.; Wegorowski, P. Corporatization in the public sector: Explaining the growth of local government companies. Public Adm. Rev. 2019, 80, 482-493. [CrossRef]

14. Voorn, B.; Van Genugten, M.; Van Thiel, S. Performance of municipally owned corporations: Determinants and mechanisms. Ann. Public Coop. Econ. 2020, 91, 191-212. [CrossRef]

15. Voorn, B. Municipally owned corporations: An introduction. In When Politics Meets Professionalism: Features and Performance Predictors of Municipally Owned Corporations; Institute for Management Research: Nijmegen, The Netherlands, 2019 ; pp. 10-45.

16. Krause, T.A.; Swiatczak, M.D. In control we trust!? Exploring formal control configurations for municipally owned corporations. J. Public Budg. Account. Financ. Manag. 2020, 33, 314-342. [CrossRef]

17. Nuti, S.; Daraio, C.; Speroni, C.; Vainieri, M. Relationships between technical efficiency and the quality and costs of health care in Italy. Int. J. Qual. Health Care 2011, 23, 324-330. [CrossRef] [PubMed]

18. Al-Darrab, I.A. Relationships between productivity, efficiency, utilization, and quality. Work. Study 2000, 49, 97-104. [CrossRef]

19. Kuo, C.-W.; Tang, M.-L. Relationships among service quality, corporate image, customer satisfaction, and behavioral intention for the elderly in high speed rail services. J. Adv. Transp. 2011, 47, 512-525. [CrossRef]

20. Chang, M.; Jang, H.-B.; Li, Y.-M.; Kim, D. The relationship between the efficiency, service quality and customer satisfaction for state-owned commercial banks in China. Sustainability 2017, 9, 2163. [CrossRef]

21. Kuo, Y.-F.; Wu, C.-M.; Deng, W.-J. The relationships among service quality, perceived value, customer satisfaction, and postpurchase intention in mobile value-added services. Comput. Hum. Behav. 2009, 25, 887-896. [CrossRef]

22. Cuadrado-Ballesteros, B.; Garcia-Sanchez, I.-M.; Prado-Lorenzo, J.-M. Effects of different modes of local public services delivery on quality of life in Spain. J. Clean. Prod. 2012, 37, 68-81. [CrossRef]

23. Gómez, J.L.Z.; Prior, D.; Díaz, A.M.P.; Hernandez, A.L. Reducing costs in times of crisis: Delivery forms in small and medium sized local governments' waste management services. Public Adm. 2012, 91, 51-68. [CrossRef]

24. Albalate, D.; Bel, G.; Calzada, J. Governance and regulation of urban bus transportation: Using partial privatization to achieve the better of two worlds. Regul. Gov. 2011, 6, 83-100. [CrossRef]

25. Pérez-López, G.; Prior, D.; Zafra-Gómez, J.L. Rethinking new public management delivery forms and efficiency: Long-term effects in Spanish local government: Table 1. J. Public Adm. Res. Theory 2015, 25, 1157-1183. [CrossRef]

26. Bourdeaux, C. Politics versus professionalism: The effect of institutional structure on democratic decision making in a contested policy arena. J. Public Adm. Res. Theory 2007, 18, 349-373. [CrossRef]

27. Samuelson, P.A. The pure theory of public expenditure. Rev. Econ. Stat. 1954, 36, 387. [CrossRef]

28. Tiebout, C.M. A pure theory of local expenditures. J. Politi. Econ. 1956, 64, 416-424. [CrossRef]

29. Musgrave, R.A. The Theory of Public Finance: A Study in Public Economy; McGraw-Hill: New York, NY, USA, 1959.

30. Buchanan, J.M. An economic theory of clubs. Economica 1965, 32. [CrossRef]

31. Hardin, G. The tragedy of the commons. Science 1968, 162, 1243-1248. [CrossRef] [PubMed]

32. Ostrom, E.; Gardner, R.; Walker, J. Rules, Games, and Common-Pool Resources; University of Michigan Press: Ann Harbour, MI, USA, 1994; ISBN 978-0-472-06546-2. 
33. Stiglitz, J.E. Economics of the Public Sector; W.W. Norton: New York, NY, USA, 2000.

34. Samuelson, P.; Nordhaus, W. Economics, 19th ed.; McGraw-Hill/Irwin: New York, NY, USA, 2009.

35. Hood, C. A public management for all seasons? Public Adm. 1991, 69, 3-19. [CrossRef]

36. Kaboolian, L. The new public management: Challenging the boundaries of the management VS. administration debate. Public Adm. Rev. 1998, 58, 189. [CrossRef]

37. Barzelay, M. The New Public Management: Improving Research and Policy Dialogue; Berkeley, University of California Press: New York, NY, USA; Russell Sage Foundation: New York, NY, USA, 2001; ISBN 978-0-520-22443-8.

38. European Commission. A Quality Framework for Services of General Interest in Europe; European Commission: Brussels, Belgium, 2011.

39. Van De Walle, S. What services are public? What aspects of performance are to be ranked? The case of "Services of general interest". Int. Public Manag. J. 2008, 11, 256-274. [CrossRef]

40. Clifton, J.; Comin, F.; Fuentes, D.D. Privatisation in the European Union: Public Enterprises and Integration; Springer Science \& Business Media: Berlin/Heidelberg, Germany, 2003.

41. Stawiarska, E.; Sobczak, P. The impact of intelligent transportation system implementations on the sustainable growth of passenger transport in EU regions. Sustainability 2018, 10, 1318. [CrossRef]

42. Cobo, S.; Dominguez-Ramos, A.; Irabien, A. From linear to circular integrated waste management systems: A review of methodological approaches. Resour. Conserv. Recycl. 2018, 135, 279-295. [CrossRef]

43. Smol, M.; Duda, J.; Czaplicka-Kotas, A.; Szołdrowska, D. Transformation towards circular economy (CE) In municipal waste management system: Model solutions for Poland. Sustainability 2020, 12, 4561. [CrossRef]

44. Di Foggia, G.; Beccarello, M. Market structure of urban waste treatment and disposal: Empirical evidence from the Italian industry. Sustainability 2021, 13, 7412. [CrossRef]

45. Brown, T.L.; Potoski, M.; Van Slyke, D.M. Changing modes of service delivery: How past choices structure future choices. Environ. Plan. C Gov. Policy 2008, 26, 127-143. [CrossRef]

46. Brown, T.L.; Potoski, M.; Van Slyke, D.M. The impact of transaction costs on the use of mixed service delivery by local governments. J. Strat. Contract. Negot. 2015, 1, 239-267. [CrossRef]

47. Bel, G.; Brown, T.; Warner, M. Editorial overview: Symposium on mixed and hybrid models of public service delivery. Int. Public Manag. J. 2014, 17, 297-307. [CrossRef]

48. Karré, P. Hybridity as a result of the marketization of public services: Catalyst or obstruction for sustainable development? Deductions from a study of three hybrid waste management organizations in The Netherlands. Sustainability 2020, $13,252$. [CrossRef]

49. Bel, G.; Hebdon, R.; Warner, M. Local government reform: Privatisation and its alternatives. Local Gov. Stud. 2007, 33, 507-515. [CrossRef]

50. Hefetz, A.; Warner, M.; Vigoda-Gadot, E. Privatization and intermunicipal contracting: The US local government experience 1992-2007. Environ. Plan. C Gov. Policy 2012, 30, 675-692. [CrossRef]

51. Witesman, E.M.; Fernandez, S. Government contracts with private organizations: Are there differences between nonprofits and for-profits? Nonprofit Volunt. Sect. Q. 2012, 42, 689-715. [CrossRef]

52. Rodrigues, M.; Tavares, A.F.; Araujo, J.F.F.E. Municipal service delivery: The role of transaction costs in the choice between alternative governance mechanisms. Local Gov. Stud. 2012, 38, 615-638. [CrossRef]

53. Brown, T.; Potoski, M. Transaction costs and contracting: The practitioner perspective. Public Perform. Manag. Rev. 2005, 28, 326-351. [CrossRef]

54. Schoute, M.; Budding, T.; Gradus, R. Municipalities' choices of service delivery modes: The influence of service, political, governance, and financial characteristics. Int. Public Manag. J. 2016, 21, 502-532. [CrossRef]

55. Brown, T.L.; Potoski, M.L. Transaction costs and institutional explanations for government service production decisions. J. Public Adm. Res. Theory 2003, 13, 441-468. [CrossRef]

56. Feiock, R.C.; Clinger, J.C.; Shrestha, M.; Dasse, C. Contracting and sector choice across municipal services. State Local Gov. Rev. 2007, 39, 72-83. [CrossRef]

57. Wassenaar, M.; Groot, T.; Gradus, R. Municipalities' contracting out decisions: An empirical study on motives. Local Gov. Stud. 2013, 39, 414-434. [CrossRef]

58. Bel, G.; Fageda, X. Why do local governments privatise public services? A survey of empirical studies. Local Gov. Stud. 2007, 33, 517-534. [CrossRef]

59. Bel, G.; Fageda, X. Factors explaining local privatization: A meta-regression analysis. Public Choice 2008, 139, 105-119. [CrossRef]

60. Koppenjan, J.F. The formation of public-private partnerships: Lessons from nine transport infrastructure projects in The Netherlands. Public Adm. 2005, 83, 135-157. [CrossRef]

61. Bognetti, G.; Robotti, L. The provision of local public services through mixed enterprises: The Italian case. Ann. Public Coop. Econ. 2007, 78, 415-437. [CrossRef]

62. Girth, A.M. What drives the partnership decision? Examining structural factors influencing public-private partnerships for municipal wireless broadband. Int. Public Manag. J. 2014, 17, 344-364. [CrossRef]

63. Feiock, R.C.; Jang, H.S. Nonprofits as local government service contractors. Public Adm. Rev. 2009, 69, 668-680. [CrossRef]

64. Warner, M.E. Competition or cooperation in urban service delivery? Ann. Public Coop. Econ. 2011, 82, 421-435. [CrossRef] 
65. Bel, G.; Warner, M. Inter-municipal cooperation and costs: Expectations and evidence. Public Adm. 2014, 93, 52-67. [CrossRef]

66. Allers, M.A.; De Greef, J. Intermunicipal cooperation, public spending and service levels. Local Gov. Stud. 2016, 44, 127-150. [CrossRef]

67. Bergholz, C. Inter-municipal cooperation in the case of spillovers: Evidence from Western German municipalities. Local Gov. Stud. 2016, 44, 22-43. [CrossRef]

68. Hefetz, A.; Warner, M. Contracting or public delivery? The importance of service, market, and management characteristics. J. Public Adm. Res. Theory 2011, 22, 289-317. [CrossRef]

69. Joassart-Marcelli, P.; Musso, J. Municipal service provision choices within a metropolitan area. Urban Aff. Rev. 2005, 40, 492-519. [CrossRef]

70. Bae, J. Institutional choices for local service contracting and collaboration. Int. Rev. Public Adm. 2009, 14, 27-42. [CrossRef]

71. Bel, G.; Warner, M. Factors explaining inter-municipal cooperation in service delivery: A meta-regression analysis. J. Econ. Policy Reform 2015, 19, 91-115. [CrossRef]

72. Silvestre, H.C.; Marques, R.C.; Gomes, R. Joined-up Government of utilities: A meta-review on a public-public partnership and inter-municipal cooperation in the water and wastewater industries. Public Manag. Rev. 2017, 20, 607-631. [CrossRef]

73. Bel, G.; Gradus, R. Privatisation, contracting-out and inter-municipal cooperation: New developments in local public service delivery. Local Gov. Stud. 2016, 44, 11-21. [CrossRef]

74. Ferry, L.; Andrews, R.; Skelcher, C.; Wegorowski, P. New development: Corporatization of local authorities in England in the wake of austerity 2010-2016. Public Money Manag. 2018, 38, 477-480. [CrossRef]

75. Torsteinsen, H. Debate: Corporatization in local government-The need for a comparative and multi-disciplinary research approach. Public Money Manag. 2018, 39, 5-8. [CrossRef]

76. Camões, P.J.; Rodrigues, M. From enthusiasm to disenchantment: An analysis of the termination of Portuguese municipal enterprises. Public Money Manag. 2020, 41, 387-394. [CrossRef]

77. Nagasawa, S.; Nagasawa, M. Free riding, empire building, and cost management prior to and post municipal enterprise mergers in Japan. Asia-Pac. J. Account. Econ. 2020, 28, 94-116. [CrossRef]

78. Tavares, A.F.; Camões, P.J. New forms of local governance. Public Manag. Rev. 2010, 12, 587-608. [CrossRef]

79. da Cruz, N.; Marques, R.C. Viability of municipal companies in the provision of urban infrastructure services. Local Gov. Stud. 2011, 37, 93-110. [CrossRef]

80. Olsen, T.H.; Solstad, E.; Torsteinsen, H. The meaning of institutional logics for performance assessment in boards of municipal companies. Public Money Manag. 2017, 37, 393-400. [CrossRef]

81. Daiser, P.; Wirtz, B.W. Strategic corporate governance factors for municipally owned companies: An empirical analysis from a municipal perspective. Int. Rev. Adm. Sci. 2019, 87, 135-153. [CrossRef]

82. Papenfuß, U.; Van Genugten, M.; De Kruijf, J.; Van Thiel, S. Implementation of EU initiatives on gender diversity and executive directors' pay in municipally-owned enterprises in Germany and The Netherlands. Public Money Manag. 2018, 38, 87-96. [CrossRef]

83. Primeaux, W.J. The effect of competition on capacity utilization in the electric utility industry. Econ. Inq. 1978, 16, 237-248. [CrossRef]

84. Pendleton, A.; McDonald, J.; Robinson, A.; Wilson, N. Employee participation and corporate governance in employee-owned firms. Work. Employ. Soc. 1996, 10, 205-226. [CrossRef]

85. Cai, J.; Tylecote, R.; Canales, I.; Kiso, T. State ownership and innovation: The relative merits of local and central state judged by innovation performance. Int. J. Innov. Manag. 2020, 25, 2150026. [CrossRef]

86. Tavares, A.F.; Camões, P.J. Local service delivery choices in Portugal: A political transaction costs framework. Local Gov. Stud. 2007, 33, 535-553. [CrossRef]

87. Krause, T.A.; Van Thiel, S. Perceived managerial autonomy in municipally owned corporations: Disentangling the impact of output control, process control, and policy-profession conflict. Public Manag. Rev. 2018, 21, 187-211. [CrossRef]

88. Sfez, S.; Dewulf, J.; De Soete, W.; Schaubroeck, T.; Mathieux, F.; Kralisch, D.; De Meester, S. Toward a framework for resource efficiency evaluation in industry: Recommendations for research and innovation projects. Resources 2017, 6, 5. [CrossRef]

89. Bull, R. Financial Ratios. How to Use Financial Ratios to Maximise Value and Success for Your Business; CIMA Publishing, Elsevier: Oxford, UK, 2008.

90. Yang, Q. Fiscal transparency and public service quality association: Evidence from 12 coastal provinces and cities of China. J. Risk Financ. Manag. 2020, 14, 13. [CrossRef]

91. Bai, C.; Lai, F.; Chen, Y.; Hutchinson, J. Conceptualising the perceived service quality of public utility services: A multi-level, multi-dimensional model. Total. Qual. Manag. Bus. Excel. 2008, 19, 1055-1070. [CrossRef]

92. Badia, F.; Bracci, E.; Tallaki, M. Quality and diffusion of social and sustainability reporting in Italian public utility companies. Sustainability 2020, 12, 4525. [CrossRef]

93. Friman, M.; Lättman, K.; Olsson, L.E. Public transport quality, safety, and perceived accessibility. Sustainability 2020, $12,3563$. [CrossRef]

94. Wagner, O.; Berlo, K.; Herr, C.; Companie, M. Success factors for the foundation of municipal utilities in Germany. Energies 2021, 14, 981. [CrossRef]

95. Cronbach, L.J. Coefficient alpha and the internal structure of tests. Psychometrika 1951, 16, 297-334. [CrossRef] 
96. Navarro-Espigares, J.L.; Torres, E.H. Efficiency and quality in health services: A crucial link. Serv. Ind. J. 2011, 31, 385-403. [CrossRef]

97. Gok, M.S.; Sezen, B. Analyzing the ambiguous relationship between efficiency, quality and patient satisfaction in healthcare services: The case of public hospitals in Turkey. Health Policy 2013, 111, 290-300. [CrossRef]

98. Kukuła, K. Metoda Unitaryzacji Zerowanej; Wydawnictwo PWN: Warsaw, Poland, 2000.

99. Młodak, A. Analiza Taksonomiczna w Statystyce Regionalnej; Difin: Warsaw, Poland, 2006.

100. Kacprzyk, D. Komunikacja Miejska w Liczbach; Izba Gospodarcza Komunikacji Miejskiej: Warsaw, Poland, 2019.

101. Schoefller, S.; Buzzell, R.D.; Heany, D.F. Impact of Strategieplanning on Profit Performance; Harvard Business Review: Cambridge, MA, USA, 1974; pp. 137-145.

102. George, S.A. Productive efficiency, service quality and profitability: A comparative analysis of foreign and private banks in India. Int. J. Prod. Qual. Manag. 2016, 18, 518. [CrossRef]

103. Zervopoulos, P.; Palaskas, T. Applying quality-driven, efficiency-adjusted DEA (QE-DEA) in the pursuit of high-efficiency-highquality service units: An input-oriented approach. IMA J. Manag. Math. 2011, 22, 401-417. [CrossRef] 